\title{
Identifying carbohydrate-active enzymes of Cutaneotrichosporon oleaginosus using systems biology
}

Tobias Fuchs, Felix Melcher, Zora Selina Rerop, Jan Lorenzen, Pariya Shaigani, Dania Awad, Martina Haack, Sophia Alice Prem, Mahmoud Masri, Norbert Mehlmer* and Thomas B. Brueck* (1)

\begin{abstract}
Background: The oleaginous yeast Cutaneotrichosporon oleaginosus represents one of the most promising microbial platforms for resource-efficient and scalable lipid production, with the capacity to accept a wide range of carbohydrates encapsulated in complex biomass waste or lignocellulosic hydrolysates. Currently, data related to molecular aspects of the metabolic utilisation of oligomeric carbohydrates are sparse. In addition, comprehensive proteomic information for C. oleaginosus focusing on carbohydrate metabolism is not available.

Results: In this study, we conducted a systematic analysis of carbohydrate intake and utilisation by C. oleaginosus and investigated the influence of different di- and trisaccharide as carbon sources. Changes in the cellular growth and morphology could be observed, depending on the selected carbon source. The greatest changes in morphology were observed in media containing trehalose. A comprehensive proteomic analysis of secreted, cell wall-associated, and cytoplasmatic proteins was performed, which highlighted differences in the composition and quantity of secreted proteins, when grown on different disaccharides. Based on the proteomic data, we performed a relative quantitative analysis of the identified proteins (using glucose as the reference carbon source) and observed carbohydrate-specific protein distributions. When using cellobiose or lactose as the carbon source, we detected three- and five-fold higher diversity in terms of the respective hydrolases released. Furthermore, the analysis of the secreted enzymes enabled identification of the motif with the consensus sequence LALL[LA]L[LA][LA]AAAAAAA as a potential signal peptide.
\end{abstract}

Conclusions: Relative quantification of spectral intensities from crude proteomic datasets enabled the identification of new enzymes and provided new insights into protein secretion, as well as the molecular mechanisms of carbohydrolases involved in the cleavage of the selected carbon oligomers. These insights can help unlock new substrate sources for C. oleaginosus, such as low-cost by-products containing difficult to utilize carbohydrates. In addition, information regarding the carbo-hydrolytic potential of C. oleaginosus facilitates a more precise engineering approach when using targeted genetic approaches. This information could be used to find new and more cost-effective carbon sources for microbial lipid production by the oleaginous yeast C. oleaginosus.

Keywords: Cutaneotrichosporon oleaginosus, Carbohydrate metabolism, Carbohydrate uptake, Proteomics, Protein secretion

*Correspondence: norbert.mehlmer@tum.de; brueck@tum.de Werner Siemens-Chair of Synthetic Biotechnology (WSSB), Technical University of Munich, Lichtenbergstraße 4, 85748 Garching, Germany

\section{Background}

The oleaginous yeast Cutaneotrichosporon oleaginosus (C. oleaginosus, ATCC20509, Agaricomycotina) is currently the most promising microorganism for original author(s) and the source, provide a link to the Creative Commons licence, and indicate if changes were made. The images or other third party material in this article are included in the article's Creative Commons licence, unless indicated otherwise in a credit line to the material. If material is not included in the article's Creative Commons licence and your intended use is not permitted by statutory regulation or exceeds the permitted use, you will need to obtain permission directly from the copyright holder. To view a copy of this licence, visit http://creativecommons.org/licenses/by/4.0/. The Creative Commons Public Domain Dedication waiver (http://creativeco mmons.org/publicdomain/zero/1.0/) applies to the data made available in this article, unless otherwise stated in a credit line to the data. 
resource-efficient microbial lipid production, that can accumulate high contents of intracellular lipids (up to $87 \% \mathrm{w} /$ d.c.w.), using sustainable and inexpensive carbon sources [1]. The genus Cutaneotrichosporon belongs to the Basidiomycota family [2]. Usually, glucose is the preferred carbohydrate source of most microorganisms [3]. However, C. oleaginosus can metabolise various carbon sources in parallel (including pentoses) without catabolic repression [4]. In particular, C. oleaginosus features an increased capacity for metabolising diverse and chemically complex carbon sources, including most mono-, di-, and trimeric sugars, as well as glycerol, volatile fatty acids, and lignin-derived aromatics [4-6]. This unique attribute provides $C$. oleaginosus with the metabolic capacity to utilise complex biomass hydrolysates derived from various biomass sources, such as lignocellulose and crude glycerol derived from biodiesel processing, without the need for detoxification. Such biomass sources have been shown to contain well-established fermentation inhibitors, such as acetic acid, furfural, and methanol [1, $7,8]$. The wide acceptance and parallel use of different carbon sources enables the efficient metabolism of complex substrates obtained from biological waste streams, including macroalgal residues [9-11]. Interestingly, toxic substances have only a minor impact on the growth of this yeast, which indicates it employs rapid adaptation mechanisms. Thus, $C$. oleaginosus can tolerate and even metabolically utilise high concentrations of acetic acid, which is not the case for the model yeast Saccharomyces cerevisiae [1].

Currently, the molecular mechanisms enabling C. oleaginosus to metabolise an extremely broad range of carbon sources, including various oligosaccharides, are unknown. Commonly, yeast cells can absorb relatively small, monomeric carbohydrate molecules through specific membrane-associated transporters [12, 13]. Thus, high-molecular-weight carbohydrates (i.e., oligosaccharides and polysaccharides, such as maltose and cellulose) cannot be directly utilised, as they must initially be cleaved to yield fermentable monomeric glucose [14]. The utilisation of complex carbohydrates requires their extracellular degradation by hydrolytic enzyme components, which generate sugar monomers that can be imported into yeast cells and metabolically utilised [15]. Alternatively, filamentous fungi, such as Trichoderma reesei, are known to secret large amounts of hydrolytic enzymes into the surrounding environment, which enable the hydrolysis and subsequent metabolic utilisation of remote, chemically complex polymeric carbon sources $[16,17]$. In other cases, cell-associated hydrolytic enzymes are found on the surface of bacterial microorganisms (such as Clostridium thermocellum) and organised as a cellulosome $[14,18]$. Due to the short distance between the cell-associated hydrolytic complex and the substrate, the high concentrations of released monomers facilitate enhanced absorption by the host. In addition, the intracellular processing of these mobilised carbohydrates by specific enzymes is required for their metabolic utilisation. Although the metabolic routes for carbohydrate uptake and consumption have been described for model yeasts such as $S$. cerevisiae and Pichia pastoris, no equivalent data are available for C. oleaginosus [19-21].

Presently, the metabolism and processing of oligomeric carbohydrates are well described for many organisms [3, 22]; however, neither comprehensive nor systematic data are available for $C$. oleaginosus. The oligomeric sugars selected in this study, are common carbohydrates comprising glucose, galactose, and fructose. All sugarsare commercially available or can be released from the hydrolytic processing of lignocellulosic sources [23].

For example, cellobiose and sucrose can be obtained from hydrolysis of wood residues and molasses distillation, respectively [24, 25]. Maltose, in contrast, can be obtained from starch-containing products, such as potato, barley and cassava, while lactose is a constituent of milk whey [26, 27]. As a first step towards elucidating the biochemical and regulatory pathways underlying the metabolic utilisation of di- and trimeric carbohydrates in C. oleaginosus, a series of glucose epimers with different linkages (Fig. 1) were used as the sole carbon source for culturing C. oleaginosus. The data were complemented with a systematic morphological and proteome analysis. Initially, the $C$. oleaginosus growth rate and morphology were assessed based on the featured disaccharides. Subsequently, a comprehensive proteomic analysis of secreted membrane protein fractions, cell wall-associated protein fractions, and cytoplasmic protein fractions was carried out. A comparative analysis of the generated liquid chromatography-tandem mass spectrometry (LC-MS/MS) data revealed significant differences $(\mathrm{p} \leq 0.05)$ between samples cultured in media containing the selected disaccharides, when compared to glucose controls. In addition, specific signal peptides for the secretion of hydrolytic proteins into the surrounding environment were identified, which represent potential targets for metabolic-engineering approaches.

\section{Results and discussion}

Evaluation of different carbohydrate effects on cellular growth, morphology and lipid formation as well as fatty acid distribution

The ability to assimilate extracellular carbohydrates is of crucial importance for most heterotrophic microorganisms. However, the cellular-uptake capacity and preference for certain carbohydrates depend on the natural habitat of the microorganism of interest and the 


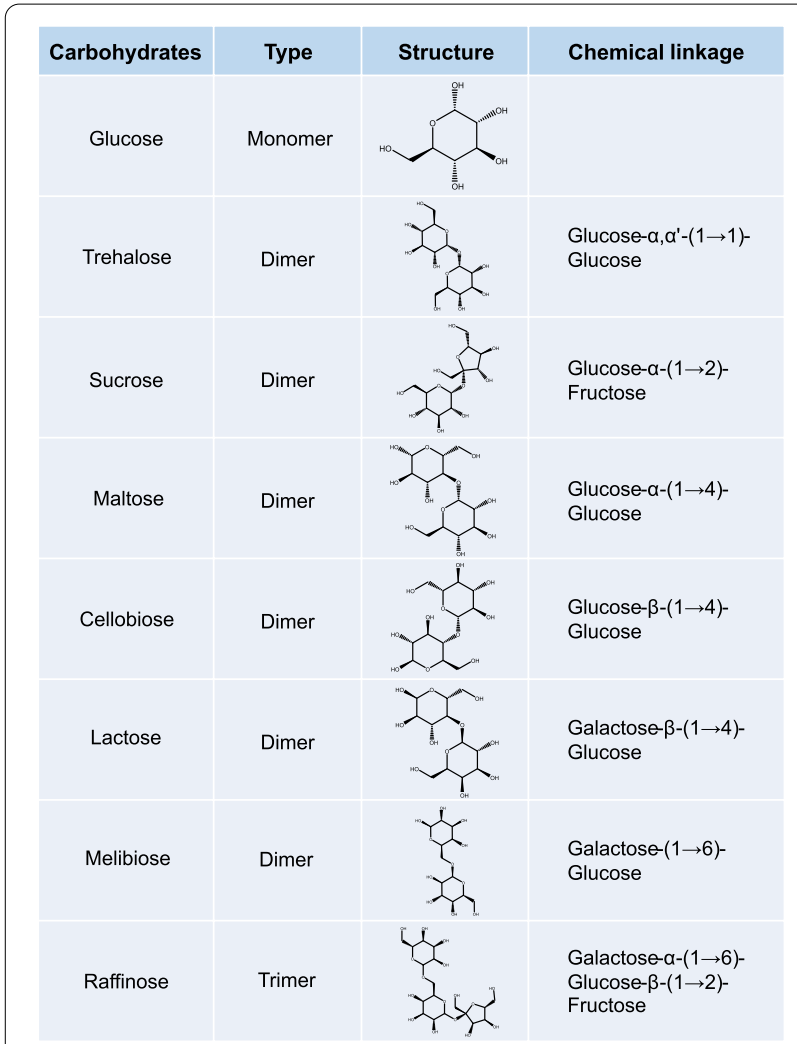

Fig. 1 Overview of the carbon sources investigated in this study, their structures, and links providing further information on the type of connection as well as their monomeric structure

prevailing environmental conditions. In complex carbohydrate mixtures such as biomass hydrolysates, the preferred carbohydrate is usually consumed first, whereas the metabolism of the other available carbohydrates is catabolically repressed [28]. Nevertheless, specific microorganisms, including C. oleaginosus, can explicitly metabolise different monomeric carbohydrates in parallel [28]. In contrast to the metabolic utilisation of monomeric carbohydrates, the use of oligomers as a carbon source has received little attention in the literature [4]. To gain insight into the metabolic mechanisms of carbohydrate oligomer utilisation, we conducted a comprehensive study to evaluate the growth kinetics, morphological changes, and enzyme-expression patterns of $C$. oleaginosus cells.

Initially, C. oleaginosus cells were cultured on yeast nitrogen base (YNB) plates containing a set of different carbohydrates. The tested carbohydrates included glucose, maltose, lactose, sucrose, cellobiose, trehalose, raffinose, and melibiose. After two days, visible growth was observed for most carbohydrates at dilutions ranging between $10^{-2}$ and $10^{-6}$. Minimal growth was detected in plates containing melibiose and raffinose. Comparing

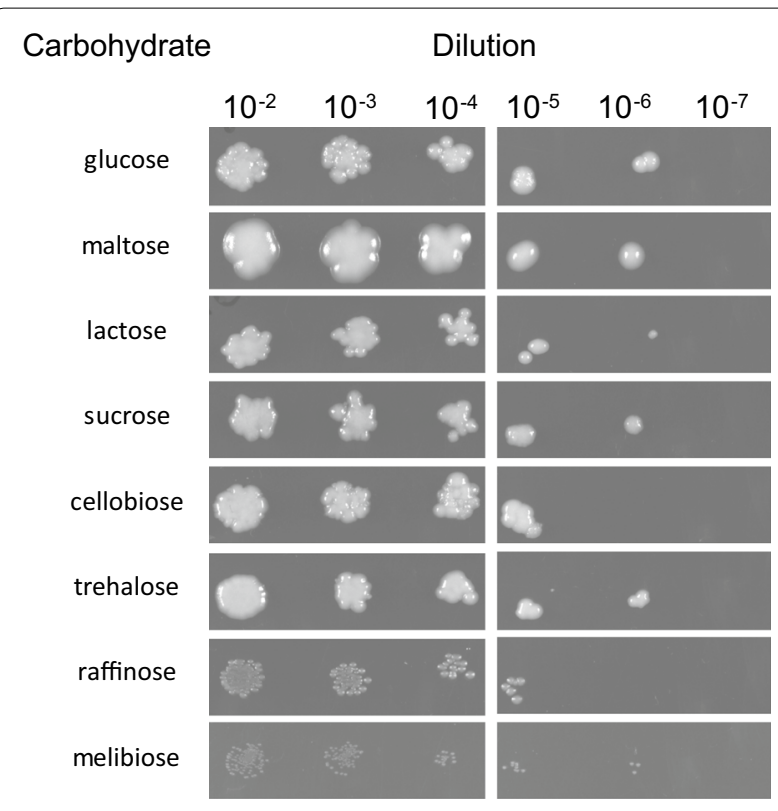

Fig. 2 Analysis of C.oleaginosus growth using different carbohydrate substrates in the medium

the phylogeny of $C$. oleaginosus with typical lipid producing yeasts (Additional file 1: Fig. S1), Trichosporon cutaneum is the closest relative and in contrast to C. oleaginosus is able to metabolise melibiose in liquid medium $[2,29]$. Furthermore, $C$. oleaginosus colonies grown on solid media containing maltose were significantly larger than those grown on media containing glucose, lactose, sucrose, cellobiose, or trehalose (Fig. 2).

As the colony size only provides limited information regarding the growth performance, a culture series was carried out in liquid media. The liquid cultures that used raffinose and melibiose as a carbohydrate substrate showed no growth. The growth as well as the specific growth rate, doubling time and lag-phase of $C$. oleaginosus cultures in the presence of the other disaccharides is depicted in Fig. 3. Differences in the growth patterns were visibly detected, depending on the carbohydrate substrate. C. oleaginosus cultures in liquid medium showed similar growth curves in the presence of sucrose and maltose. The sucrose and maltose samples reached final optical density at $600 \mathrm{~nm}\left(\mathrm{OD}_{600}\right)$ values of 4.75 and 4.85 , which were twice as high as those cultured with glucose and cellobiose, respectively. Previously, other filamentous fungi such as Mortierella isabellina grew two times faster on glucose than on sucrose [30]. C. oleaginosus in media supplemented with sucrose, maltose, or lactose exhibited similar growth rates, with the latter showing the slowest growth. After $42 \mathrm{~h}$, these cultures showed a final $\mathrm{OD}_{600}$ value of 4.11. Although cellobiose cultures grew similarly to the glucose reference cultures, 


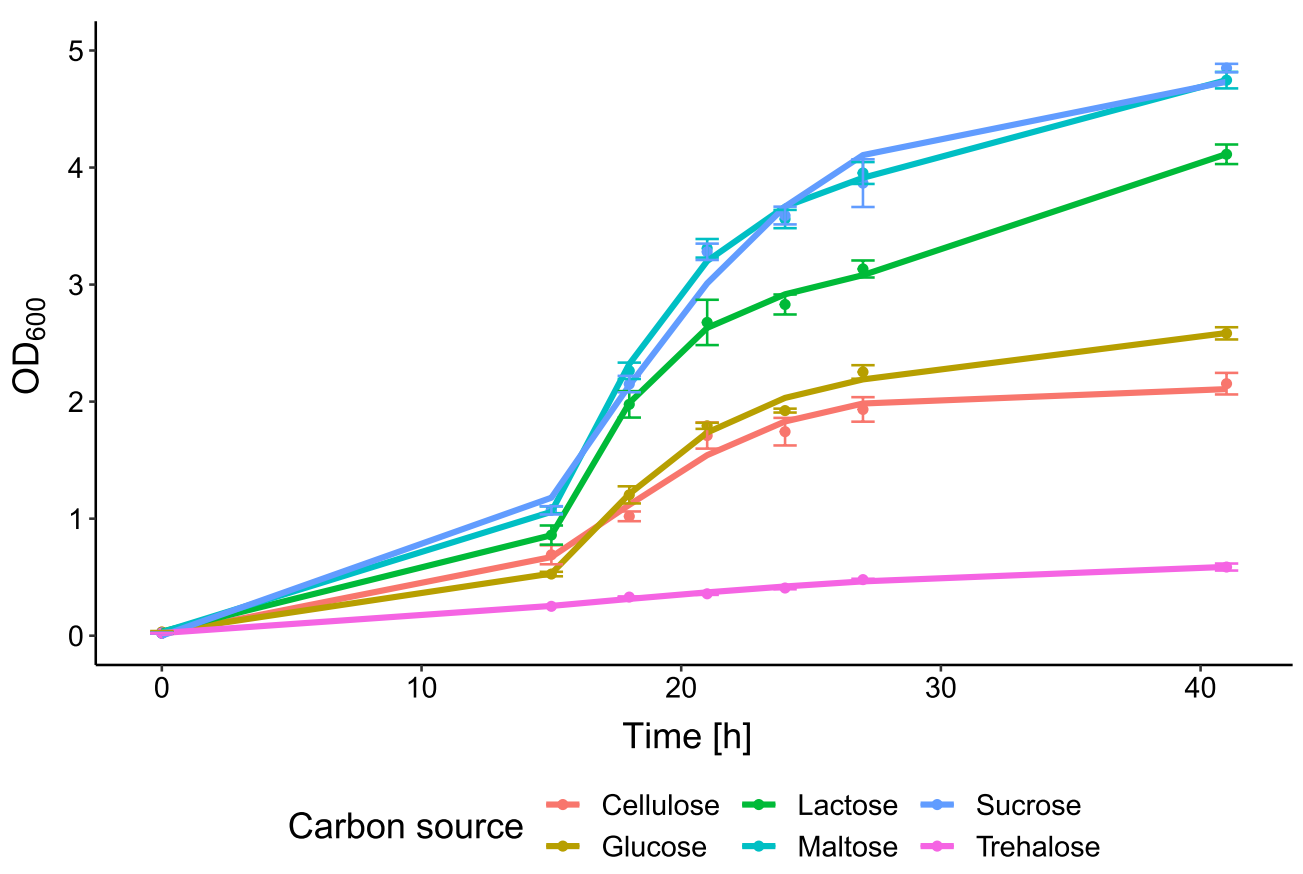

\begin{tabular}{|c|c|c|c|c|c|c|}
\hline$\#$ & Sugar & $\mathbf{A}$ & $\boldsymbol{\mu}$ & $\boldsymbol{\Lambda}$ & integral & Doubling time [h] \\
\hline 1 & Cel & $2.150 \pm 0.11$ & $0.169 \pm 0.03$ & $11.160 \pm 1.14$ & 48.67 & 4.52 \\
\hline 2 & Glu & $2.556 \pm 0.09$ & $0.199 \pm 0.02$ & $12.114 \pm 0.69$ & 54.30 & 3.87 \\
\hline 3 & Lac & $4.093 \pm 0.29$ & $0.237 \pm 0.04$ & $10.470 \pm 1.55$ & 85.38 & 3.29 \\
\hline 4 & Mal & $4.670 \pm 0.19$ & $0.341 \pm 0.04$ & $11.527 \pm 0.82$ & 100.66 & 2.27 \\
\hline 5 & Suc & $4.790 \pm 0.22$ & $0.325 \pm 0.04$ & $11.405 \pm 0.93$ & 101.15 & 2.36 \\
\hline 6 & Tre & $0.653 \pm 0.03$ & $0.020 \pm 0.00$ & $2.490 \pm 1.32$ & 13.84 & 32.71 \\
\hline
\end{tabular}

Fig. 3 Upper panel: C. oleaginosus growth curves in media supplemented with different carbohydrates. Lower panel: max. growth (A), specific growth rate $(\mu)$, lag-phase $(\lambda)$ and doubling time. The parameters were calculated in R using gompertz as model

a slightly reduced growth curve was observed with cultures supplemented with cellobiose, as confirmed by their final $\mathrm{OD}_{600}$ values of 2.15 and 2.58 , respectively. These results differ from the growth-rate data for $T$. cutaneum described by Mörtberg and colleagues [29]. In contrast to $C$. oleaginosus, $T$. cutaneum grew almost identically in media supplemented with glucose, maltose, lactose, sucrose, cellobiose, or melibiose [29]. However, both strains showed similar decreases in their growth rates when the culture medium was supplemented with trehalose [29].

To examine morphological changes occurring with the yeast cells, the samples were collected during the exponential growth phase. Significant differences in length: width ratio were observed for cultures supplemented with cellobiose, maltose, sucrose, or trehalose compared to those supplemented with glucose (control; Fig. 4 and Additional file 2: Fig. S2). A significant increase in the cell length was observed in cellobiose-supplemented cultures, whereas the width increased in maltose-supplemented cultures. Furthermore, the cells cultured in media supplemented with sucrose or trehalose showed the biggest differences in the length: width ratio, indicating that an increase in the length occurred. Notably, the cultures supplemented with trehalose displayed a more round- to rod-shaped morphology, compared to that found in cultures supplemented with glucose. In the Basidiomycota, morphological changes are common in the course of sexual reproduction [31, 32]. Furthermore, changes in morphology of yeasts have already been demonstrated in Yarrowia lipolytica using $\mathrm{N}$-glycosamine and serum to induce the formation of hyphaes [33, 34]. In addition, ambient temperature can affect cell size and morphology on S. cerevisiae [35]. Notably, this is the first study describing morphological changes in oleaginous yeasts in response to the supplied carbohydrate source during fermentation. In order to analyse the effects of different carbohydrates on lipid production, lipogenesis 


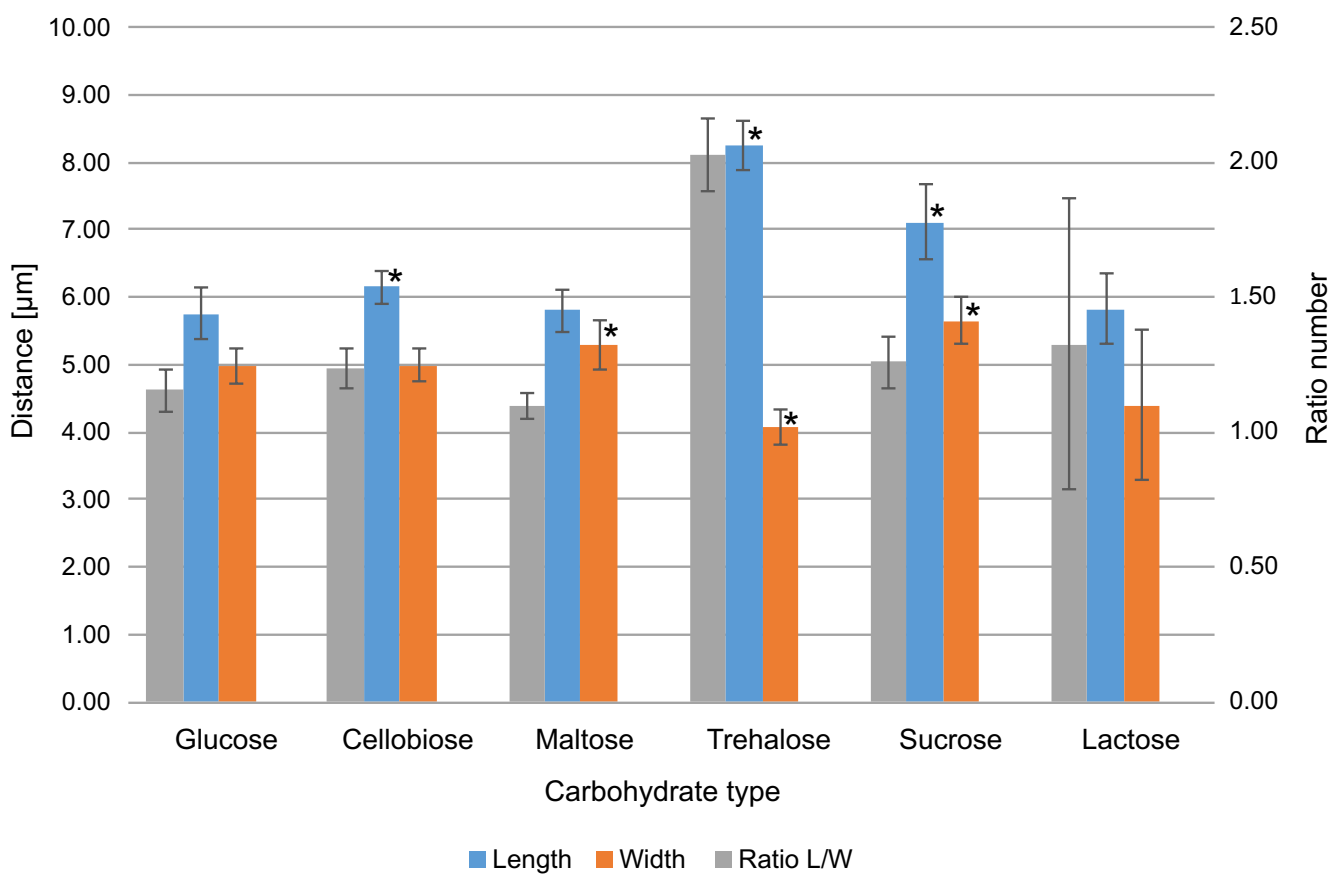

Fig. 4 Morphological variations of C. oleaginosus in different culture media. The measured lengths and diameters of the C. oleaginosus cells in different cell media are shown. Additionally, the ratio length: width is shown on the secondary axis. The asterisks indicate a significant difference compared to the glucose condition $(p<0.05)$

in C. oleaginosus was induced under nitrogen limiting growth conditions [4].The distribution of the identified fatty acids, as well as their quantities is shown in Additional file 3: Fig. S3a and b. The lowest fatty acid amount compared to the glucose control was detected in the cultures growing on trehalose with $9.5 \%$ (w/dcw, weight/ dry cell weight). In contrast, lactose showed the highest fatty acid accumulation with $29.08 \%$ (w/dcw). Maltose, cellobiose and sucrose also resulted in elevated fatty acid yields compared to the glucose control (see Additional file 3: Fig. S3a). Furthermore, as described in a previous study, the fatty acid profile (Additional file 3: Fig. S3b) shows that maltose and lactose have a similar fatty acid distribution as the glucose control [4]. However, a slight reduction in oleic acid, as well as an increase in palmitic acid and stearic acid, as described by Awad, could be detected [4]. The most significant influence on the fatty acid profiles could be observed in cultures containing Trehalose. Interestingly, for the Trehalose grown cultures a shift in the proportion of linoleic acid and $\alpha$-linoleic acid by a factor of 1.58 and 3.12 respectively could be detected with reference to the glucose control. Moreover, the proportion of oleic acid was reduced by a factor of 0.72 compared to the reference culture. At present, there is no biochemical data that could be used to delineate this effect. Currently, detailed metabolomics studies are underway in our research group to address the required data sets.

\section{Effects of different disaccharides on the distributions of enzyme classes}

The effects of different disaccharides on selected protein fractions isolated from the cytoplasm, cell wall, and secretions of $C$. oleaginosus were analysed. The selected carbon sources directly influenced the types and quantities of proteins expressed in C. oleaginosus, thus providing information regarding the uptake and metabolism of the respective carbon source.

The high data quantity and quality generated in this study enabled sequence-based analysis of the identified proteins. Initially, overlapping and fraction-specific proteins for the selected carbohydrates were analysed and visualised using Venn diagrams (Additional file 4: Fig. S4). In the secreted fraction of cells cultured in medium supplemented with cellobiose or lactose, the highest numbers of total and carbohydrate-modified proteins were detected. Additionally, an ontology-based classification of the proteins into classes such as biological processes, molecular functions, and cellular components was performed (Additional file 5: Fig. S5. Additional file 6: Fig. S6, Additional file 7: Fig. S7). Within this dataset, an approximately equal distribution of each protein group 
was observed, whereas the total number of proteins per group varied.

To functionally analyse the identified proteins expressed under specific carbohydrate conditions and compare them to the reference condition (glucose), a classification of their respective enzyme commission (EC) numbers was performed. The subsequent assignments of each fraction (secreted, cell wall-associated, and cytoplasmic), as well as the respective carbon source, are shown in Fig. 5. The EC numbers did not vary significantly for the cytoplasmic fraction when compared to those of the reference condition (Fig. 5c); however, the EC number distributions of the cell wall-associated enzyme fractions were significantly different when comparing the diverse carbohydrate sources with that of the reference condition (Fig. 5b). The lactose and trehalose datasets indicated a two-fold enhancement in various hydrolase activities (enzyme class 3). Significant differences in the EC numbers were also detected in yeast cultures in medium supplemented with maltose, except for the class of ligases (enzyme class 6).

Interestingly, the distributions of the enzyme classes found in the secretome showed the greatest quantitative differences. This contrasts the situation in the yeast $P$. pastoris, whose secretion profile hardly changed, when cultivated with different carbon sources [36]. As shown in Fig. $5 \mathrm{a}$, a relatively small number of proteins per enzyme class could be detected under the glucose condition ( $\leq 10$ different enzymes per enzyme class). Compared to the glucose condition, significant increases in the diversity of different enzyme classes were detected with all disaccharides investigated. Significant increases in enzyme diversities were observed under all conditions, particularly with enzyme class 1 (oxidoreductases) and class 4 (lyases). Notably, lactose and cellobiose showed significant differences in their hit numbers within all enzyme classes; lactose and cellobiose showed a four-fold increase in the number of enzyme class 3 (hydrolases) and a seven-fold increase in lactose and cellobiose, when compared to those observed under the glucose condition.

For an in-depth analysis of the hydrolases used to cleave individual disaccharides, the enzymes of subclass EC 3.2 (glycosylases) were further investigated.

\section{Influences of distinct carbohydrates on the expression of secreted hydrolases}

A detailed proteomic analysis of the effects of sugar substrates on the expression of hydrolytic enzymes revealed significant differences, when comparing the glucose condition with the other carbohydrate conditions. Figure 6 shows that the hydrolases identified under the glucose condition were downregulated compared to those observed in cultures grown in disaccharide-containing media. However, as shown in Fig. 7, numerous enzymes were specifically produced that could potentially cleave the investigated disaccharides. The predictions of the potential functions of the identified enzymes are shown in Additional file 8: Fig. S8.

\section{Cellobiose}

For the secretome cultured in media supplemented with cellobiose, a significant upregulation of the proteins $\mathrm{H} 4$ (ß-1,3-1,4-glucanase), H6 (glucan endo-1,3-ß-glucosidase), and H5 ( $\alpha$-amylase) was observed. Six-fold and two-fold upregulations in $\mathrm{H} 6$ and $\mathrm{H} 4$ were observed, and these proteins shared $29.4 \%$ and $44.29 \%$ sequence identity with previously reported $ß$-glucosidases, respectively $[37,38]$. Moreover, H5 was the most upregulated (16fold) under the cellobiose condition (when compared to the glucose condition), and it shared $39.32 \%$ sequence identity with $\alpha$-amylase [39]. In addition, the hydrolase H15 (exo-B-(1,3)-glucanase), which was only detected in cultures grown in cellobiose-containing media, exhibited a $42.5 \%$ sequence identity to a $B$-bond-cleaving enzyme [40].

\section{Lactose}

Secretome analysis of the cells cultured in lactose-containing media also showed upregulation of the $\mathrm{H} 6$ and $\mathrm{H} 5$ proteins. The four-fold upregulation of hydrolase $\mathrm{H} 5$ was lower than that observed in cells cultured in cellobiose-containing media; however, it differed significantly from the expression observed in cells cultured in glucosecontaining media. These results indicate that the $B$-glucosidase $\mathrm{H} 6$ was released by $C$. oleaginosus cells for the cleavage of different disaccharides linked by $\beta-1,4$ glycosidic bonds. These findings are consistent with the results of Nakkharat et al., who demonstrated that $\beta$-glucosidase from the thermophilic fungus Talaromyces thermophilus CBS 236.58 can also exhibit $ß$-galactosidase activity [41].

\section{Maltose}

Using maltose as the carbon source led to upregulation of the $\mathrm{H} 5$ and $\mathrm{H} 6$ proteins in the secreted protein fraction of C. oleaginosus cultures. H5 expression was upregulated nine-fold compared to that observed under the glucose condition. Furthermore, in silico analysis identified $\mathrm{H} 5$ as an $\alpha$-amylase responsible for maltose cleavage. In addition, the $\mathrm{H} 2$ enzyme $(\alpha / \beta$-glucosidase) was detectable almost exclusively in C. oleaginosus cultured in maltose-supplemented medium. This enzyme might cleave the $\alpha$ position of sugar compounds due to its $39.3 \%$ sequence identity match with a previously described $\alpha / \beta$ glucosidase [37]. 
a 80.00

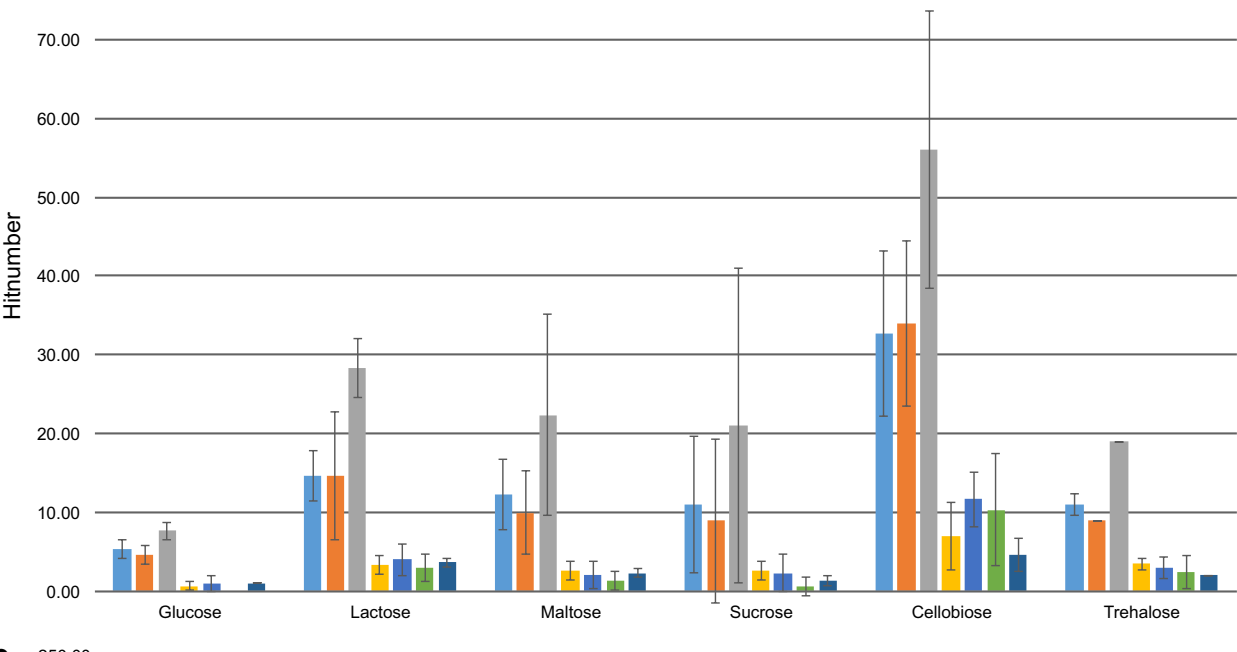

b 250.00

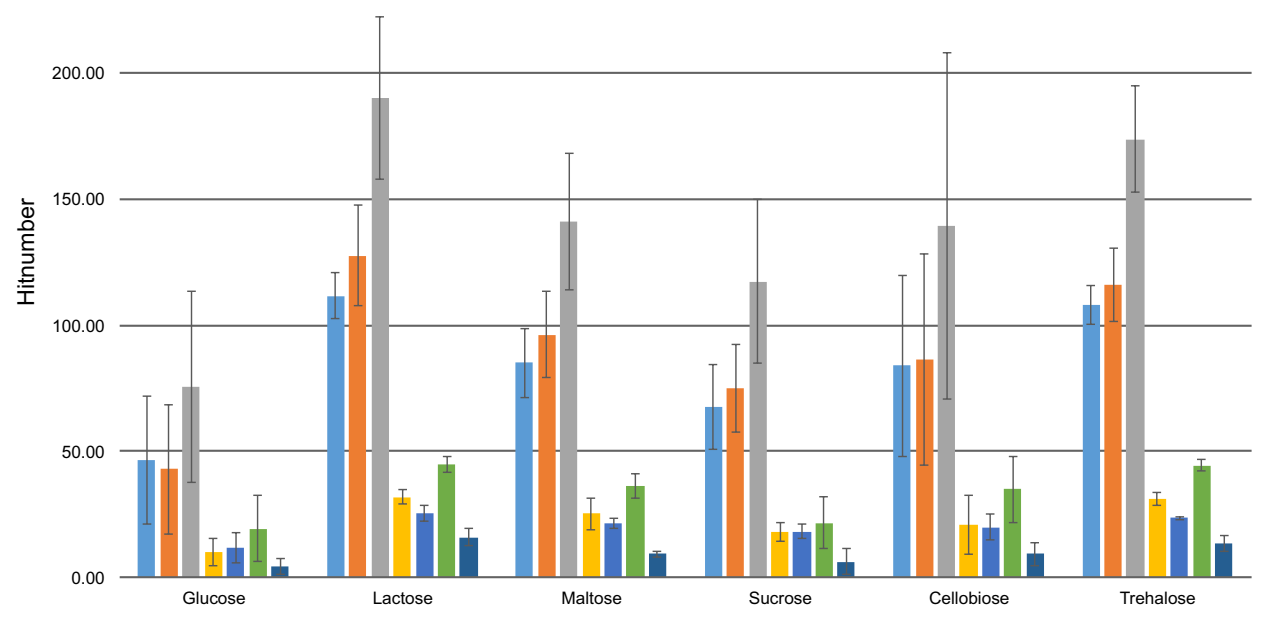

C

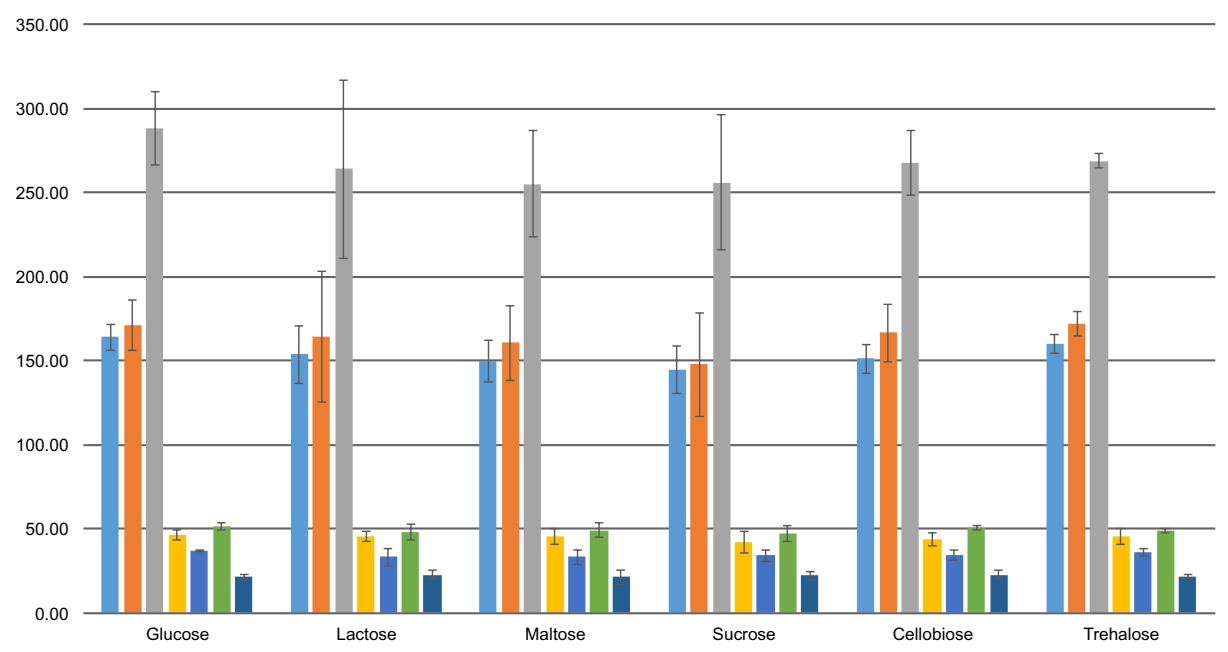

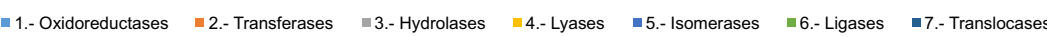

Fig. 5 Enzyme hit distribution. For each carbohydrate, the numbers of different enzymes identified (based on the EC number) are shown for the secreted, cell wall-associated, and cytoplasmic fractions 


\begin{tabular}{|c|c|c|c|c|c|c|c|c|c|c|c|c|c|}
\hline & \multicolumn{7}{|c|}{ cytoplasmic hydrolases } \\
\hline & & & & & & & NR & ID & Cel & Lac & Mal & Suc & Tre \\
\hline \multicolumn{2}{|c|}{ Minimum } & \multicolumn{2}{|c|}{-} & \multicolumn{3}{|c|}{ Maximum } & $\mathrm{H} 20^{* \star}$ & A0A0J0XQV4 & 2.80 & $3.49^{* \star}$ & $6.53^{\star *}$ & $1.43^{\star *}$ & $1.17^{\star \star}$ \\
\hline & 0.5 & & 1 & 1.5 & \multicolumn{2}{|c|}{$\leq 2$} & $\mathrm{H} 21$ & A0A0J1BBF9 & 1.13 & 0.80 & 1.30 & 0.85 & 1.44 \\
\hline & & & & & & & $\mathrm{H} 1$ & A0A0J1BEM6 & 0.84 & 0.80 & $0.61^{*}$ & 0.73 & 1.31 \\
\hline & $\mathrm{H} 8$ & A0A0J0XB79 & 0.85 & $0.39^{*}$ & 0.49 & 0.80 & 0.18 \\
\hline & & & & & & & $\mathrm{H} 22$ & AOAOJOXCH8 & 0.73 & $1.09^{* \star}$ & $1.43^{* \star}$ & $0.00^{*}$ & 1.99 \\
\hline \multicolumn{7}{|c|}{$\begin{array}{l}\text { secreted hydrolases } \\
\begin{array}{l|c|c|c|}\text { Cel } & \text { Lac } & \text { Mal }\end{array}\end{array}$} & $\mathrm{H} 23$ & A0A0J0XIP5 & 0.71 & 0.73 & 1.05 & 1.43 & $2.14^{*}$ \\
\hline $\mathrm{H} 1$ & A0A0J1BEM6 & 1.22 & $0.60^{*}$ & 1.37 & $1.46^{*}$ & 2.69 & $\mathrm{H} 24$ & A0A0J0XDB8 & $0.55^{\star}$ & 0.70 & 1.00 & 1.15 & 0.65 \\
\hline $\mathrm{H} 3$ & A0A0J0XCY7 & $0.24^{*}$ & $0.50^{*}$ & $0.81^{*}$ & 0.64 & 0.00 & $\mathrm{H} 25$ & A0A0J0XZ69 & $0.58^{\star *}$ & $0.00^{*}$ & $0.00^{*}$ & $0.61^{*}$ & $0.36^{*}$ \\
\hline $\mathrm{H} 4$ & A0A0J0XDY7 & $2.02^{*}$ & 0.60 & $0.89^{\star *}$ & $2.74^{* *}$ & $1.43^{\star \star}$ & $\mathrm{H} 29^{\star \star}$ & A0A0J0XQT4 & 0.00 & 0.00 & $4.18^{\star \star}$ & 0.00 & 0.00 \\
\hline $\mathrm{H} 5^{\star *}$ & A0A0J0XT28 & $16.10^{*}$ & $4.79^{*}$ & 9.63 & $16.68^{*}$ & $10.20^{*}$ & $\mathrm{H} 31$ & A0A0J0XSL4 & $2.82^{\star \star}$ & $0.74^{\star \star}$ & 0.00 & 0.00 & $0.60^{\star \star}$ \\
\hline $\mathrm{H} 6$ & A0A0J0XNE6 & $5.65^{*}$ & $6.05^{*}$ & 3.13 & $5.45^{\star \star}$ & $1.35^{\star *}$ & $\mathrm{H} 32^{\star *}$ & A0A0JOXLQ1 & $15.20^{*}$ & $15.20^{*}$ & 1.64 & 2.58 & 0.00 \\
\hline $\mathrm{H7}$ & A0A0JOXJB9 & $0.00^{*}$ & 0.13 & 0.00 & 0.00 & 0.00 & $\mathrm{H} 12^{\star \star}$ & A0A0J0XM56 & $6.25^{*}$ & 0.85 & 0.00 & 0.00 & 1.39 \\
\hline \multirow{2}{*}{\multicolumn{7}{|c|}{ cell associated hydrolases }} & $\mathrm{H} 6$ & A0A0JOXNE6 & $1.61^{*}$ & 0.93 & 0.57 & 0.61 & 1.00 \\
\hline & & & & & & & $\mathrm{H} 34$ & A0A0JOXQN3 & 1.43 & 0.93 & 0.48 & 0.66 & 1.13 \\
\hline NR & ID & Cel & Lac & Mal & Suc & Tre & $\mathrm{H} 5$ & A0A0J0XT28 & 1.34 & 0.79 & $0.71^{\star \star}$ & 0.93 & 0.88 \\
\hline $\mathrm{H} 8$ & A0A0J0XB79 & 0.71 & 0.18 & 0.25 & 0.29 & 0.48 & $\mathrm{H} 11$ & A0A0J0XWG8 & 0.90 & 0.57 & 1.00 & 0.99 & 1.35 \\
\hline $\mathrm{H} 1$ & A0A0J1BEM6 & $0.28^{*}$ & $0.12^{*}$ & $0.45^{*}$ & $0.24^{*}$ & $0.28^{*}$ & $\mathrm{H} 13^{\star \star}$ & A0A0J1AV63 & 0.39 & 0.72 & 0.65 & 0.49 & 1.13 \\
\hline $\mathrm{H} 2$ & A0A0J0XHCO & $0.00^{*}$ & $0.00^{*}$ & 1.79 & 0.00 & $0.08^{*}$ & $\mathrm{H} 14$ & A0A0J1B7V0 & $0.13^{*}$ & $0.04^{*}$ & $4.75^{\star}$ & $2.35^{*}$ & 1.03 \\
\hline $\mathrm{H}^{* *}$ & A0A0J0XCY7 & $0.53^{*}$ & $0.29^{*}$ & $1.38^{*}$ & $0.97^{*}$ & $0.28^{*}$ & $\mathrm{H} 35$ & A0A0J1B1F9 & $0.00^{*}$ & $0.00^{*}$ & $4.08^{*}$ & $4.77^{*}$ & $2.29^{* \star}$ \\
\hline $\mathrm{H} 9$ & A0A0J0XBX5 & $0.70^{\star \star}$ & $0.15^{*}$ & 0.78 & $0.78^{*}$ & $0.22^{\star \star}$ & $\mathrm{H} 36$ & A0A0J0XRK3 & 0.00 & 0.00 & 1.10 & 0.00 & 1.21 \\
\hline $\mathrm{H} 4$ & A0A0J0XDY7 & $0.61^{* *}$ & $0.14^{*}$ & 0.52 & $0.19^{*}$ & $0.11^{*}$ & $\mathrm{H} 16$ & A0A0J0XMG2 & $2.36^{*}$ & 0.83 & 0.60 & \begin{tabular}{|l|l}
$0.42^{*}$ \\
\end{tabular} & 0.92 \\
\hline $\mathrm{H} 10^{* *}$ & $\mathrm{~A} 0 \mathrm{~A} 0_{2}$ & 0.16 & 0.17 & 0.90 & 0.22 & 0.07 & H39 & A0A0J1ASG6 & 1.71 & 1.11 & 0.94 & 0.00 & 1.22 \\
\hline $\mathrm{H} 12$ & A0A0J0XM56 & 0.92 & 0.20 & 0.53 & 0.30 & 0.26 & $\mathrm{H} 40$ & A0A0J0XZM7 & 0.97 & 0.45 & 0.86 & 1.20 & 1.00 \\
\hline $\mathrm{H} 6$ & A0A0J0XNE6 & 0.56 & $0.43^{*}$ & 0.77 & 0.75 & $0.33^{*}$ & $\mathrm{H} 41$ & A0A0JOXKP2 & 0.75 & 0.71 & 0.63 & 1.02 & 1.04 \\
\hline $\mathrm{H} 13$ & $\mathrm{AOAO}$ & 0.49 & $0.23^{*}$ & 0.83 & $0.57^{\star \star}$ & $0.30^{*}$ & $\mathrm{H} 42$ & A0A0J1B5L2 & 0.73 & 0.60 & 1.25 & 1.83 & 0.75 \\
\hline $\mathrm{H} 5$ & A0A0J0XT28 & 0.57 & 0.24 & 0.78 & $0.36^{*}$ & $0.29^{*}$ & $\mathrm{H} 43$ & A0A0J1AZB4 & $0.45^{*}$ & $0.62^{\star \star}$ & $0.00^{*}$ & $0.41^{\star \star}$ & 1.04 \\
\hline $\mathrm{H} 15^{\star \star}$ & $\mathrm{A} 0 \mathrm{AO}$ & 0.00 & $0.15^{* \star}$ & 0.00 & $0.18^{\star \star}$ & 1.36 & $\mathrm{H} 44^{\star \star}$ & AOAOJOXIC5 & $0.96^{* \star}$ & 0.00 & $0.42^{\star \star}$ & 0.00 & 1.31 \\
\hline $\mathrm{H} 16$ & A0A0J0XMG2 & 0.67 & 0.16 & 0.35 & 0.16 & 0.21 & $\mathrm{H} 46$ & A0A0JOXHA3 & 1.23 & 0.63 & 0.66 & 1.04 & 0.74 \\
\hline $\mathrm{H} 17$ & A0A0J1B677 & $0.30^{*}$ & \begin{tabular}{|l|l|}
$0.09^{*}$ \\
\end{tabular} & 0.55 & $0.20^{*}$ & $0.23^{*}$ & $\mathrm{H} 47$ & A0A0J1BA01 & 0.90 & $0.61^{* \star}$ & 0.52 & 0.96 & $0.55^{\star \star}$ \\
\hline $\mathrm{H} 18$ & A0A0J0XJI2 & 0.15 & 0.18 & 0.73 & 0.26 & 0.13 & $\mathrm{H} 49$ & A0A0J0XV52 & $0.74^{*}$ & $19.85^{\star}$ & $0.73^{*}$ & $0.50^{*}$ & $1.52^{\star}$ \\
\hline $\mathrm{H} 19$ & A0A0J & 0.54 & 0.30 & 0.84 & 0.53 & 0.45 & $\mathrm{H} 19$ & A0A0J0XSP4 & 0.87 & $0.68^{* \star}$ & $0.62^{\star \star}$ & 0.00 & 1.19 \\
\hline $\mathrm{H} 7$ & A0A0J0XJB9 & $0.24^{* *}$ & $0.04^{*}$ & $0.05^{*}$ & 0.06 & $0.00^{*}$ & $\mathrm{H} 50^{* \star}$ & A0A0J0XC30 & 0.49 & $0.87^{\star \star}$ & 1.26 & 0.00 & 3.19 \\
\hline
\end{tabular}

Fig. 6 Relative expression levels of the hydrolases identified under each carbohydrate condition, normalised to the expression levels measured under the glucose condition. The identified putative hydrolases are listed, and their relative expression levels compared to that observed under the glucose condition are indicated. Significant differences $(p<0.05)$ are indicated with an asterisk. Values based on duplicates are marked with two asterisks

\section{Sucrose}

Analysis of the secreted protein fraction of cultures grown in sucrose-containing media revealed upregulation of proteins $\mathrm{H} 1$ (endo-1,3(4)- 3 -glucanase), H4, H5, and H6. $\mathrm{H} 5$ and $\mathrm{H} 6$ were the most upregulated proteins, exhibiting 17-fold and five-fold increases in expression, respectively. Surprisingly, although it cleaves sucrose, the H3 protein (invertase), which partly corresponds to an invertase, was downregulated. Since C. oleaginosus cells showed efficient growth in sucrose medium, this finding suggests that sucrose might not be hydrolysed extracellularly by $C$. oleaginosus cells; instead, membrane-associated, or intracellular processes might perform this function. This is in line with previously published data [29] describing the incapacity of T. cutaneum to hydrolyse sucrose extracellularly.

\section{Trehalose}

C. oleaginosus cultured in media supplemented with the disaccharide trehalose showed upregulation of the $\mathrm{H} 1$ (endo-1,3(4)-beta-glucanase), $\mathrm{H} 4, \mathrm{H} 5$, and $\mathrm{H} 6$ proteins in the secreted fractions. Although a relatively high upregulation of the $\mathrm{H} 1$ and $\mathrm{H} 5$ proteins was detected (17-fold and seven-fold, respectively), these proteins do not seem to be involved in trehalose hydrolysis, as indicated by the negative enzyme test.

The results of the substrate tests with concentrated protein fractions from the C. oleaginosus cultures are shown in Additional file 9: Fig. S9. The enzymatic tests indicated that $C$. oleaginosus can extracellularly hydrolyse disaccharides such as cellobiose, lactose, and maltose. However, sucrose and trehalose do not appear to be hydrolysed by the secreted proteins in the respective cultures. These results distinguish $C$. oleaginosus from the 


\begin{tabular}{|c|c|c|c|c|c|c|}
\hline \multicolumn{7}{|c|}{ secreted hydrolases } \\
\hline NR & ID & Cel & Lac & Mal & Suc & Tre \\
\hline $\mathrm{H} 8$ & A0A0J0XB79 & 43451 & 4014 & $9206^{* *}$ & $9238^{* *}$ & 18802 \\
\hline $\mathrm{H} 31$ & A0A0JOXSL4 & 10246 & $608^{\star \star}$ & 7753 & 0 & 1212 \\
\hline $\mathrm{H} 18$ & A0A0J0XH28 & $15222^{\star *}$ & 0 & 0 & $8212^{\star *}$ & 0 \\
\hline $\mathrm{H} 32$ & A0A0J0XLQ1 & $1701^{\star \star}$ & 0 & 0 & 0 & 0 \\
\hline $\mathrm{H} 2$ & AOAOJOXHCO & 0 & 0 & 125027 & $606^{\star *}$ & 0 \\
\hline $\mathrm{H} 15$ & A0A0J1BBW0 & $6306^{\star *}$ & 0 & 0 & 0 & 0 \\
\hline $\mathrm{H} 13$ & A0A0J1AV63 & 6052 & $2540^{\star *}$ & 4536 & $4644^{* *}$ & 974 \\
\hline $\mathrm{H} 12$ & A0A0J0XM56 & 24650 & 0 & 0 & 0 & 2988 \\
\hline $\mathrm{H} 48$ & A0A0J0XBA7 & 17576 & 0 & 0 & 0 & 32675 \\
\hline $\mathrm{H} 18$ & AOA0J0XJI2 & $5655^{\star \star}$ & 0 & 0 & 0 & 0 \\
\hline $\mathrm{H} 19$ & A0A0J0XSP4 & 2346 & 0 & 0 & 0 & 0 \\
\hline \multicolumn{7}{|c|}{ cell wall-associated hydrolases } \\
\hline NR & ID & Cel & Lac & Mal & Suc & Tre \\
\hline $\mathrm{H} 14$ & A0A0J1B7V0 & 0 & 0 & 47317 & 12526 & 0 \\
\hline $\mathrm{H} 11$ & A0A0J0XWG8 & $10771^{\star \star}$ & 15290 & 4219 & $3322^{* *}$ & 11969 \\
\hline $\mathrm{H} 21$ & A0A0J1BBF9 & $639^{\star *}$ & 0 & 0 & $0^{* *}$ & 0 \\
\hline $\mathrm{H} 51$ & A0A0J0XYB4 & 0 & 0 & 0 & $2169^{\star \star}$ & 0 \\
\hline $\mathrm{H} 26$ & A0A0J0XES7 & 0 & $1835^{\star *}$ & 0 & 0 & 0 \\
\hline $\mathrm{H} 52$ & A0A0J0XN97 & 0 & 0 & $747^{* *}$ & 3913 & 0 \\
\hline $\mathrm{H} 28$ & A0A0J0XCW3 & 0 & 16498 & 0 & 0 & 0 \\
\hline $\mathrm{H} 30$ & A0A0J1AWU3 & 27809 & 58182 & 0 & 0 & 0 \\
\hline $\mathrm{H} 35$ & A0A0J1B1F9 & 0 & 0 & $1372^{* *}$ & 4813 & 0 \\
\hline $\mathrm{H} 34$ & A0A0J0XQN3 & $5966^{\star \star}$ & 6682 & $2301^{* *}$ & $1335^{\star *}$ & $1982^{\star *}$ \\
\hline $\mathrm{H} 32$ & A0A0J0XLQ1 & 71501 & 66186 & $1757^{\star \star}$ & $952^{\star \star}$ & 3063 \\
\hline H53 & A0A0J0XGU5 & 0 & 0 & $1090^{* *}$ & 0 & 0 \\
\hline $\mathrm{H} 41$ & A0A0J0XKP2 & 0 & 1621 & 0 & 18379 & $1255^{\star \star}$ \\
\hline $\mathrm{H} 44$ & A0A0JOXIC5 & 0 & $481^{* *}$ & 0 & 0 & 0 \\
\hline H39 & A0A0J1ASG6 & 0 & 1191 & 0 & $939^{* *}$ & $714^{* *}$ \\
\hline $\mathrm{H} 46$ & A0A0J0XHA3 & 0 & 0 & 0 & 0 & $763^{\star \star}$ \\
\hline $\mathrm{H} 47$ & A0A0J1BA01 & $1525^{\star *}$ & $1228^{* *}$ & 0 & 28044 & $904^{\star *}$ \\
\hline $\mathrm{H} 48$ & A0A0J0XBA7 & $2057^{\star \star}$ & 0 & 0 & 0 & 13584 \\
\hline $\mathrm{H} 49$ & A0A0J0XV52 & 0 & 91149 & $1623^{* *}$ & 0 & 2880 \\
\hline $\mathrm{H} 50$ & A0A0J0XC30 & 0 & 0 & $782^{\star \star}$ & 0 & 2105 \\
\hline \multicolumn{7}{|c|}{ cytoplasmic hydrolases } \\
\hline NR & ID & Cel & Lac & Mal & Suc & Tre \\
\hline $\mathrm{H} 26$ & A0A0J0XES7 & 2461 & $5568^{* *}$ & 0 & 0 & 0 \\
\hline $\mathrm{H} 27$ & A0A0J0XGS2 & 4677 & $7861^{* \star}$ & 0 & 0 & 0 \\
\hline $\mathrm{H} 28$ & A0A0J0XCW3 & 0 & 16226 & 0 & 0 & 0 \\
\hline $\mathrm{H} 9$ & A0A0J0XBX5 & 1411 & $616^{\star \star}$ & $919^{* \star}$ & 0 & 0 \\
\hline $\mathrm{H} 30$ & A0A0J1AWU3 & 35035 & 59077 & 0 & 0 & $1062^{\star *}$ \\
\hline $\mathrm{H} 33$ & A0A0J0XBA4 & $1039^{\star \star}$ & 0 & $751^{* \star}$ & 0 & $\underline{0}$ \\
\hline $\mathrm{H} 37$ & A0A0J1AUQ8 & 0 & 0 & 0 & 0 & $1492^{\star *}$ \\
\hline $\mathrm{H} 38$ & A0A0J0XGW6 & 0 & 0 & $1012^{\star \star}$ & 0 & $3278^{* \star}$ \\
\hline $\mathrm{H} 48$ & A0A0J0XBA7 & $8382^{\star *}$ & 0 & 0 & 0 & 0 \\
\hline $\mathrm{H} 55$ & A0A0J0XV92 & 0 & 0 & 0 & 0 & $1260^{* *}$ \\
\hline $\mathrm{H} 56$ & A0A0J0XU26 & 0 & 0 & 0 & 0 & $855^{\star *}$ \\
\hline $\mathrm{H} 57$ & A0A0J0XIZ6 & 0 & $1743^{* *}$ & 0 & 0 & $1310^{* *}$ \\
\hline $\mathrm{H} 2$ & $\mathrm{AOAOJOXHCO}$ & 659 & 0 & $1554^{* *}$ & 0 & 0 \\
\hline $\mathrm{H} 10$ & A0A0J0XH28 & 0 & 0 & 0 & 0 & $743^{\star *}$ \\
\hline $\mathrm{H} 60$ & A0A0J1BAM0 & 0 & $1633^{\star *}$ & 0 & 0 & 0 \\
\hline $\mathrm{H} 17$ & A0A0J1B677 & 0 & 0 & 0 & $356^{\star \star}$ & 0 \\
\hline
\end{tabular}

Fig. 7 Expression levels of the identified hydrolases. The hydrolases detected exclusively in the disaccharide-supplemented cultures are shown

closely related yeast $T$. cutaneum, which cannot extracellularly hydrolyse cellobiose, lactose, and maltose, but can hydrolyse sucrose and trehalose [29].
Influences of different carbohydrate sources on membrane- and cell wall-associated hydrolases

Membrane- and cell wall-associated proteins play key roles in the recognition and uptake of extracellular carbohydrates [42]. A proteome analysis was performed to further elucidate the protein abundances and expression patterns in C. oleaginosus.

\section{Cellobiose}

All hydrolases detected in C. oleaginosus cultured in glucose-containing media were downregulated when cultured in media supplemented with cellobiose. However, as shown in Fig. 7, the H11 (1,4-alphaglucan-branching enzyme), H21 ( $\alpha / \beta$-hydrolase), H30 (ß-glucosidase), H34 (glycoside hydrolase), H32 ( $\beta$-mannosidase), H47 ( $\alpha$-amylase), and H48 ( $\beta$-galactosidase) enzymes (which were not detectable under the glucose condition) were identified. The presence of the H30, H32, and H47 enzymes is of importance because they might be able to cleave the $\beta$-bound cellobiose, based on reference database entries [43-45].

\section{Lactose}

The H26 ( $\alpha$-galactosidase), H28 (ß-galactosidase), H30, $\mathrm{H} 34, \mathrm{H} 32$, and H47 enzymes were identified under the lactose condition, but not under the reference glucose condition. H26 and $\mathrm{H} 28$ shared over $45 \%$ sequence identity to galactosidases detected in Paecilomyces thermophila and Arthrobacter sp. respectively [37, 46]. Furthermore, under the lactose condition, the hydrolase $\mathrm{H} 30$ was upregulated three-fold compared to that observed under the cellobiose condition. Like hydrolase H6, this hydrolase seems to be able to cleave cellobiose and lactose.

\section{Maltose}

The $\mathrm{H} 2(\alpha / \beta$-glucosidase $)$ and $\mathrm{H} 3$ enzymes were upregulated in yeast cultured in maltose-containing media, compared to yeast cultured in glucose-containing media. The changes in responses to maltose were most prominent amongst the responses to the other disaccharides. The $\mathrm{H} 2$ enzyme, which appears to play a role in the extracellular hydrolysis of maltose, was upregulated two-fold. In addition, enzymes such as H14 ( $\alpha$-glucosidase), H52 (glycosyl hydrolase), H35 ( $\alpha$-glucosidase), or H34 were over 36\% identical to putative maltose-cleaving enzymes (Fig. 7). In particular, H14 displayed a six-fold upregulation and shares homology to the $\alpha$-glucosidase expressed in Halomonas sp. [47]. 


\section{Sucrose}

The H35, H51 ( $\alpha / \beta$-hydrolase), H52, H47, and H14 enzymes play dominant roles in the hydrolysis of sucrose, a carbohydrate with high relevance to industrial fermentation. The H47 enzyme-expression level was at least 28 -fold higher under the sucrose condition than under other culture conditions. Furthermore, based on its homology to $\alpha$-glucosidase, H14 might be able to cleave maltose and sucrose [47]. We could further infer that other enzymes, such as H52 and H35, are also formed in the presence of sucrose and maltose (Fig. 7). This may indicate that both disaccharides partly induce the same protein-expression profiles in C. oleaginosus. This bifunctionality has already been described by Williamson et al. for other yeast maltases [48]. In this study, a potential $\alpha$-cleaving enzyme, H51, was exclusively detected under the sucrose condition.

\section{Trehalose}

When the culture medium was supplemented with trehalose, the H11, H32, H48, H50 (neutral trehalase), and H46 ( $\alpha$-glucosidase) enzymes were strongly expressed. Notably, the H46 enzyme was only detected under the trehalose condition. Furthermore, this enzyme exhibits $45 \%$ sequence identity to a previously described $\alpha$-glucosidase [49]. Moreover, the H50 enzyme exhibits a $50 \%$ sequence identity to the yeast trehalase identified by Alblova et al. [50]; its expression was upregulated at least three-fold in C. oleaginosus cultured in trehalose-containing media compared to that observed in C. oleaginosus cultured in glucose-containing media.

\section{Influences of different carbohydrates on the expression of soluble cytoplasmic hydrolases}

To gain a better understanding of intracellular carbon utilisation, cytoplasmic enzymes were further examined. The obtained data are presented in Figs. 6 and 7, and the regulations and annotations of the identified cytoplasmic enzymes are illustrated.

\section{Cellobiose}

A detailed examination of the cultures obtained from cellobiose-containing media indicates that nine potential hydrolases are upregulated. The $\mathrm{H} 20(\alpha / \beta$-hydrolase), H31 (glucan 1,3-beta-glucosidase), H32, and H12 (exo-ß3$(1,3)$-glucanase) enzymes showed at least two-fold higher expression levels compared to those observed in cultures obtained from glucose-containing media. The corresponding identities match at least $34 \%$ with $\beta$-cleaving enzymes. The most dramatic change was observed for the H32 enzyme, which was identified in the other fractions. This specific putative $B$-mannosidase, which matches a $ß$-mannosidase detected in Myceliophthora thermophila
[44], showed a 15-fold upregulation in cultures obtained from cellobiose-containing media. Moreover, H30 was also detected in the cytoplasmic fraction when the yeast cells were cultured in media supplemented with cellobiose or lactose.

\section{Lactose}

A similar expression pattern can be induced by lactose in the culture medium. In lactose-containing media, the H32 enzyme was the most upregulated, and the H30 enzyme-expression level increased 1.4-fold compared to that observed in cultures obtained from cellobiosecontaining media. The formation of $\mathrm{H} 32$ and $\mathrm{H} 30$ in cellobiose- and lactose-based cultures indicates that $C$. oleaginosus utilises these enzymes to cleave cellobiose and lactose, respectively. Furthermore, it can be concluded that $C$. oleaginosus expresses specific enzymes to cleave various $\beta$-bound monosaccharides. Interestingly, H28 was only detected in cultures grown in lactosesupplemented media. Finally, H28 shares $45 \%$ sequence identity with a $B$-galactosidase previously detected in Arthrobacter sp. 32cB [46].

\section{Maltose}

Under the maltose condition, the expression levels of the $\mathrm{H} 20, \mathrm{H} 14$, and H35 enzymes were upregulated two-fold compared to those observed under the glucose condition. These enzyme sequences correspond to $\alpha$-cleaving enzymes, which might play a role in cytoplasmic maltose cleavage. Further, H14 and H35 match the sequences of well-characterised glucosidases identified in the Halomonas sp. and Bacillus cereus bacteria $[47,51]$. In addition, the data in Fig. 7 indicate the formation of the $\mathrm{H} 2$ enzyme, which might play a dominant role in the previously discussed secretomes of maltose-based yeast cultures.

\section{Sucrose}

As shown in Fig. 6, sucrose induced the expression of the H14, H35, H42 (acylpyruvate hydrolase), and H32 enzymes. The H14 and H35 enzymes showed at least 36\% sequence identity to the $\alpha$-glycosidases previously identified in Halomonas sp. and Schizosaccharomyces pombe $[47,52]$. In addition, H20 was identified as an enzyme with $59.5 \%$ similarity to the sequence of a modelled $a / \beta$ hydrolase.

\section{Trehalose}

Finally, the formation of $\alpha-1,1$-bound trehalose-cleaving hydrolases was analysed. The H22 (putative dienelactone hydrolase), H23 ( $\alpha / \beta$-hydrolase), and H35 ( $\alpha$-glucosidase) enzymes were upregulated two-fold under the trehalose condition, compared to the glucose 
condition. The $\mathrm{H} 23$ enzyme shares $51 \%$ sequence identity with an $\alpha / \beta$ hydrolase. Furthermore, as shown in Fig. 7 , the H55 ( $\alpha / \beta$-hydrolase), H56 ( $\alpha / \beta$-hydrolase), and $\mathrm{H} 10$ (glucan endo-1,3- $\alpha$-glucosidase agn1) enzymes were only detected in the cytoplasmic fraction of C. oleaginosus cultured in trehalose-containing media. H55 and $\mathrm{H} 56$ share over $50 \%$ homology with $\alpha / \beta$-hydrolases. These enzymes can cleave the $\alpha-1,1$ bond of trehalose into glucose monomers. In addition, the expression of the potential trehalase $\mathrm{H} 50$, which was identified in the cell wall-associated fraction, was increased three-fold under the trehalose condition, compared to that under the glucose condition. Enzymes such as H2, H30, and H26 were disregarded from the analysis since they can cleave other disaccharides. Although the $\mathrm{H} 2$ enzyme was produced in the secretome of cultures obtained from trehalose-containing media, the dinitrosalicylic acid (DNS) test did not detect $\mathrm{H} 2$-specific activity.

\section{The C. oleaginosus hydrolase composition enabled} metabolic utilisation of chemically distinct disaccharides

Conducting a detailed analysis of the carbohydrate metabolism is the first step in understanding the versatile substrate use of $C$. oleaginosus. Therefore, we investigated different dimers and trimers, among the glucose epimers. In the following sections, the obtained data are interpreted, and the results are graphically summarised in Fig. 8.

\section{Cellobiose}

Yeast cultures grown in cellobiose-based medium reached an $\mathrm{OD}_{600}$ of 2.15 after $42 \mathrm{~h}$, which was the second-lowest value observed among all carbohydratebased medium conditions tested. All analysed fractions contained different putative cellobiose-cleaving enzymes. The reduced growth on liquid cellobiose-containing medium could be explained by the higher galactosidase activity of the identified $B-1-4$ cleaving enzymes. This finding further explains the expression of these hydrolases in C. oleaginosus cells cultured in lactose-containing medium. Furthermore, it has been documented that the same glycosyl hydrolase activity can cleave several carbohydrates with different substrate affinities [41]. In addition, the high number of $\beta$-glucosidases expressed suggests that $C$. oleaginosus might cleave cellobiose intracellularly. This possibility is further supported by observations that cellulolytic fungi can carry out intracellular hydrolysis of cellobiose [53].

\section{Lactose}

Yeasts cultured in lactose-supplemented media reached an $\mathrm{OD}_{600}$ of 4.11, which was two-fold higher than that observed under the cellobiose condition. Since many

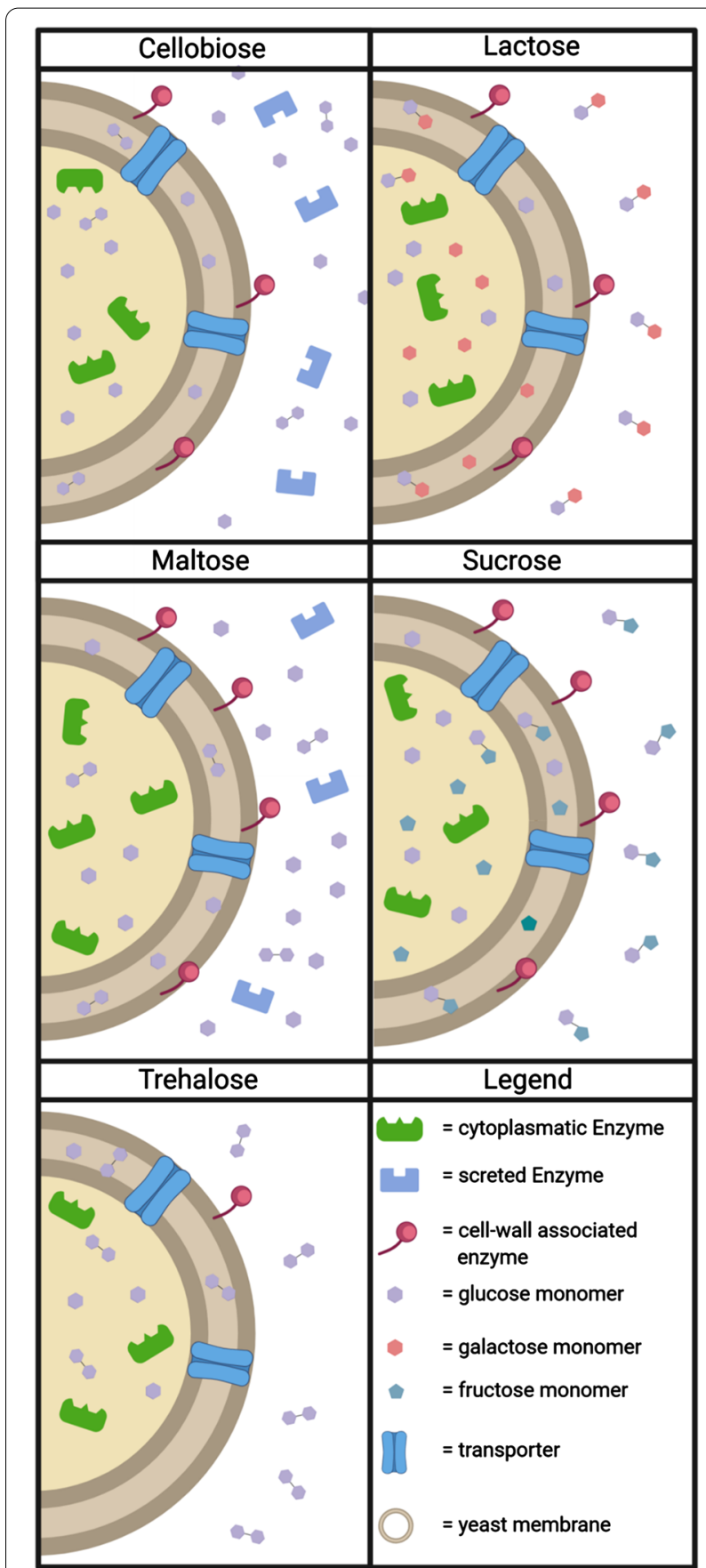

Fig. 8 Representative model of disaccharide cleavage and uptake in C. oleaginosus. The model illustrates the potential cleavage in the subcellular or extracellular compartment and subsequent uptake of carbohydrates by C. oleaginosus. The model schematically indicates which fractions (secreted, cell wall-associated, or cytoplasmic) contained the enzymes necessary for cleaving the indicated disaccharides 
enzymes are expressed during growth based on either carbohydrate, we hypothesise that they have a higher enzymatic activity for the substrate lactose. In addition, C. oleaginosus exhibited increased expression of enzymes such as $\mathrm{H} 30$ and $\mathrm{H} 20$ in lactose-based cultures, when compared to that in cellobiose-based cultures. An indication of the localisation of lactose cleavage in $C$. oleaginosus is provided by the observation that galactosidases (such as $\mathrm{H} 26$ and $\mathrm{H} 28$ ) were produced, which are mainly found in the membrane and in the cytoplasm. In addition, an associated lactose permease was identified, which indicates that $C$. oleaginosus might primarily degrade lactose at the membrane or intracellularly. However, Carvalho-Silva and Spencer-Martins showed that lactose can be cleaved extracellularly in various Kluyveromyces marxianus strains [54]. Positive activity for lactose cleavage in the secreted fractions of $C$. oleaginosus (Additional file 9: Fig. S9) further supports this observation. In contrast, the intracellular utilisation of this carbohydrate differs in C. oleaginosus from that in the related strain $T$. cutaneum, which predominantly degrades lactose extracellularly [29].

\section{Maltose}

For yeast cultured in maltose-containing medium, the highest biomass increase was determined at an $\mathrm{OD}_{600}$ of 4.75 , whereas sucrose-based cultures reached an $\mathrm{OD}_{600}$ of 4.85. The significant increase in $\mathrm{H} 2$ expression in the presence of maltose in the secretome highlights the efficient cleavage of this disaccharide. Additional enzymes, such as $\mathrm{H} 20$ and H14, were upregulated in the membrane and cytoplasm. These findings support the conclusion that C. oleaginosus, similar to Cryptococcus flavus, secretes amylases and efficiently cleaves maltose extracellularly [55]. However, this is not the case for T. cutaneum and many brewery yeasts $[29,56]$. Since $C$. oleaginosus enzymes such as $\mathrm{H} 20$ and $\mathrm{H} 14$ are upregulated in the membrane and cytoplasm, other metabolic pathways are activated in parallel to the extracellular cleavage of maltose [57].

\section{Sucrose}

Compared to other disaccharide-based cultures, the cultures grown in sucrose-based medium showed the highest cell density, with an $\mathrm{OD}_{600}$ of 4.85 after $42 \mathrm{~h}$. Furthermore, our current analysis indicated that C. oleaginosus cannot degrade sucrose extracellularly, in contrast to $S$. cerevisiae [58]. However, some potential sucrosecleaving enzymes, such as H11, H14, H20, and H35, were identified in the membrane and cytoplasmic fractions. These findings suggest that $C$. oleaginosus cleaves sucrose substrate intracellularly and/or via a membrane-associated process. This hypothesis is supported by positive enzyme activity observed in the cell wall fraction, as well as numerous studies that have investigated the utilisation of sucrose in yeast [58].

\section{Trehalose}

Among the disaccharides investigated, the trehalosebased cultures showed the slowest growth. Although a high number of different hydrolases were observed in the membrane and cytoplasmic fractions of $C$. oleaginosus, only the detected trehalases are related to trehalose cleavage and cell growth. In addition, trehalose is often used as a storage compound or formed as part of a stress response towards dehydration or increased ethanol levels [59]. This suggests that trehalose is less suitable for $C$. oleaginosus cultivation.

\section{Analysis of secreted proteins}

Proteins targeted toward the secretory pathway are mediated by the endoplasmic reticulum (ER)-Golgi endomembrane pathway. This is the first step in the recognition of signal sequences (such as the signal-recognition particle) and association with the ER [60]. Further protein sorting within the endomembrane system is regulated by specific sequence motifs, followed by specific glycosylation processes [61]. Thus, identifying these sequence motifs is important for improving the understanding of subcellular protein sorting and subsequent protein secretion.

To identify new signal motifs, all 1,091 secreted proteins with a $-10 \cdot \operatorname{lgP}$ value higher than 36 were analysed for potential signal peptides using the SignalP5.0, Phobius, and WoLF PSORT software programs. These analyses identified 112 proteins with potential eukaryotic signal-peptide motifs. These hits represented candidate signal sequences that potentially function to introduce proteins to the secretion pathway by triggering their transport into the ER.

The 112 hits were further analysed using the MEME tool (from MEME Suite 5.1.1) for novel motif elicitation against a background dataset of the 1,000 most abundant cytoplasmic enzymes. A 15 amino acid-long motif was identified, which was present in 81 of the 112 proteins $(p=9.4 e-007)$. The motif comprises a stretch of the hydrophobic amino acids, alanine and leucine, with the consensus sequence LALL[LA]L[LA][LA]AAAAAAA (Fig. 9). Furthermore, the motif is primarily located at the amino termini of the proteins, as a part of the predicted signal peptide, which have a hydrophobic character [62]. Nevertheless, in eight cases, the motif was also found at the $\mathrm{C}$-terminal side and in some rare cases, in the middle of the protein.

Amongst the 1,091 secreted proteins selected, the consensus motif was found in 358 cases $(p<0.0001)$. When 


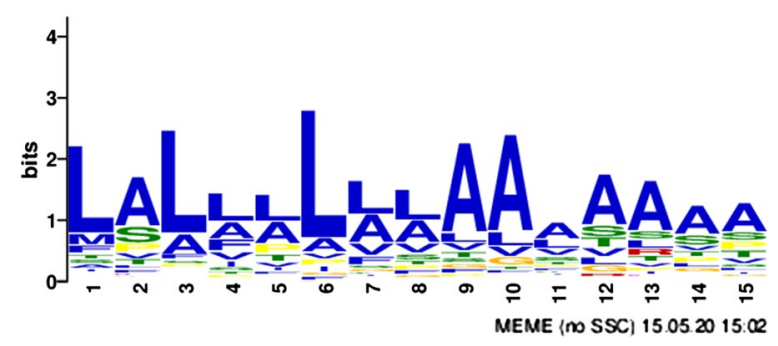

Fig. 9 Identification of the LALA motif (Logo). The LALA motif was identified in the N-terminal sequences of 81 of 112 potential signal peptide sequences, using MEME Suite 5.1.1 [88]

screening for the motif within the 4,498 cytoplasmic proteins detected in this study, 1,107 hits were obtained. These findings might suggest that the motif belongs to a signal peptide that triggers transport into the ER, but has no direct influence on protein secretion itself. To trigger protein secretion from the ER to Golgi and out of the cell, another signal is required, such as a pro-peptide with a certain glycosylation pattern. For the yeast $S$. cerevisiae, a combination of signal peptides (pre-peptide and propeptide) similar to the glycosylated pro- $\alpha$-mating factor can lead to protein secretion [63]. Moreover, P. pastoris is an established host for the production of recombinant, secreted proteins [64]. The signal sequence for secretion is reported and can be fused to the recombinant protein to initiate cellular export. In addition, $Y$. lipolytica is also able to efficiently secrete proteins. Several secretion signals have been described and corresponding expression systems generated [65-68].

In the secreted protein fraction, glycosylated peptides could be identified (Additional file 12: Table S1). Within this dataset, the most abundant carbohydrate-based post-translational modifications were derived from glucose (delta molecular weight [MW]: 162.05), heptose (delta MW: 192,06), hexosamine (delta MW: 161.07), gluconoyl (delta MW: 178.05), and fucose (delta MW: 146.06). Within this dataset, numerous carbohydraterelated proteins that are potentially involved in cellular export were discovered. In addition, some of these glycolytic motifs were identified in hydrolases $\mathrm{H} 1, \mathrm{H} 6, \mathrm{H} 8$, $\mathrm{H} 13, \mathrm{H} 12, \mathrm{H} 31$, and $\mathrm{H} 32$.

\section{Conclusions}

The presence, uptake, and utilisation of different disaccharides in C. oleaginosus were studied using a comprehensive approach involving proteomic and morphological analyses. In this work, we addressed the influence of a selected set of different di- and trisaccharides as carbon sources for the first time in C. oleaginosus, followed by a wide proteomic analysis of expressed proteins.
In addition, the target compartments of the proteins were considered, including cytoplasmic, cell-associated, and secreted proteins. Based on spectral information, the relative quantification of specific proteins was possible, which provided insights into the potential functions of the newly identified proteins. The subsequent assignment of the individual proteins to their enzyme classes helped uncover information regarding their formation and functions. Significant differences in the relative abundances of each substrate in the different fractions were also detected. For example, the addition of lactose or cellobiose-compared to the glucose reference-respectively resulted in three- and five-fold higher diversities of hydrolases (enzyme class 3 ) in the secretome. Significant increases in expression, such as the formation of $\mathrm{H} 2(\alpha / \beta$-glucosidase $)$ when maltose was added or $\mathrm{H} 20$ $(\alpha / \beta$-hydrolase) and H30 ( $\beta$-glucosidase) when cellobiose and lactose were used as substrates, were observed. In conclusion, the most prominent enzymes including $\mathrm{H} 26, \mathrm{H} 28, \mathrm{H} 30, \mathrm{H} 32$ and H47, exhibiting $\alpha$-galactosidase, $\beta$-galactosidase, $\beta$-glucosidase, $\beta$-mannosidase and $\alpha$-amylase activities respectively are summarized in Additional file 10: Fig. S10. Furthermore, a phylogenetic comparison of the identified hydrolases has revealed sequence and functional relationships (Additional file 11: S11). For example, the annotated $\alpha / \beta$-glucosidase activity is found in the nearby branch of $\mathrm{H} 2, \mathrm{H} 20, \mathrm{H} 21$ and $\mathrm{H} 25$. Moreover, the annotated $\beta$-galactosidase activity is associated with the nearby branch of $\mathrm{H} 28$ and $\mathrm{H} 30$. The cumulative phylogenetic comparison therefore increased the confidence in our functional assignment of the identified proteins. In addition, by analysing the secreted enzymes, a motif with the consensus sequence LALL[LA] L[LA][LA]AAAAAAA was identified as a potential signal peptide. These insights reveal potential new substrate sources for C. oleaginosus, such as inexpensive metabolic by-products containing utilizable carbohydrates. Gathering information regarding the carbo-hydrolytic potential of $C$. oleaginosus allows for more precise engineering approaches. This information could be used to discover more cost-effective carbon sources for microbial lipid production by C. oleaginosus.

\section{Methods}

\section{Spot assay for $C$. oleaginosus}

A liquid culture of C. oleaginosus containing $10^{7}$ yeast cells $/ \mathrm{mL}$ was diluted from $10^{-2}$ to $10^{-10}$ and spotted on solid media plates containing $6.7 \mathrm{~g} / \mathrm{L}$ YNB (Carl Roth $\mathrm{GmbH}+\mathrm{Co}$. KG, Karlsruhe, Germany), supplemented with $20 \mathrm{~g} / \mathrm{L}$ of the indicated carbohydrates and $20 \mathrm{~g} / \mathrm{L}$ agarose. The plates were incubated for two days at $28{ }^{\circ} \mathrm{C}$. 


\section{C. oleaginosus cultures}

C. oleaginosus (ATCC 20,509) cells were cultured in media containing YNB (6.7 g/L) supplemented with $20 \mathrm{~g} / \mathrm{L}$ of the indicated carbohydrates. The yeast were cultured in baffled Erlenmeyer flasks on a rotary shaker at 120 rotations $/ \mathrm{min}$ and $28{ }^{\circ} \mathrm{C}$. The cells were inoculated in $30 \mathrm{~mL}$ culture medium containing glucose and incubated for $24 \mathrm{~h}$. The pre-cultures were used to inoculate $500 \mathrm{~mL}$ baffled Erlenmeyer flasks containing $150 \mathrm{~mL}$ YNB medium at an $\mathrm{OD}_{600}$ of 0.1 , which were then incubated for 3 days. The cells were harvested via centrifugation at $6,738 \times g$ for $7 \mathrm{~min}$, re-suspended in $150 \mathrm{~mL}$ fresh medium (without carbohydrates), and transferred in baffled Erlenmeyer flasks. After the addition of maltose, lactose, cellobiose, sucrose, trehalose, or glucose (control), the cells were cultured for 2 additional days. Each experiment was carried out in triplicate. The cultivation for the fatty acid analysis was carried out under the same conditions with an elongated cultivation time of 5 days under limiting conditions by reducing the ammonium sulphate content (nitrogen limitation) from 5.0 to $0.613 \mathrm{~g} / \mathrm{l}$.

\section{Fatty acid analysis}

The fatty acid analysis was carried out according to the method of Griffiths et. al. with the modifications of Woortman et. al. [69, 70].

\section{Nile red staining and microscopy}

The yeast cells were photographed using a microscope (Axio Lab.A1, Carl Zeiss AG, Oberkochen, Germany). Nile red staining was performed according to a previously described method [71].

\section{Protein extraction}

Initially, secreted proteins were separated from the cells by centrifugation at $6,738 \times g$ for $7 \mathrm{~min}$. Cell-associated proteins were washed off the cells by re-suspension in $25 \mathrm{~mL} \mathrm{NaCl}(150 \mathrm{mM})$. After a $10 \mathrm{~min}$ incubation at room temperature (RT, approximately $22{ }^{\circ} \mathrm{C}$ ), the associated protein fraction was separated from the cells by centrifugation at $20,133 \times g$ for $7 \mathrm{~min}$. The remaining cell pellet was re-suspended in $15 \mathrm{~mL} \mathrm{NaCl}(150 \mathrm{mM})$ and disrupted using a high-pressure homogeniser ( 8 bar; Avestin Europe GmbH, Mannheim, Germany). The soluble cytoplasmic protein fraction was separated from the cell debris by centrifugation at $20,133 \times g$ for $7 \mathrm{~min}$. In the second step, the secreted, membrane-associated, and cytoplasmic protein fractions were each filtered through a $0.45 \mu \mathrm{m}$ filter to remove residual cellular material, precipitated with $10 \%$ trichloroacetic (v/v) acid for $30 \mathrm{~min}$ at $4{ }^{\circ} \mathrm{C}$, and subsequently centrifuged at $20,133 \times g$ for $10 \mathrm{~min}$ at $4{ }^{\circ} \mathrm{C}$. The precipitated proteins were washed twice with $10 \mathrm{~mL}$ methanol (high-performance liquid chromatography [HPLC] grade) and three times with $10 \mathrm{~mL}$ acetone (HPLC grade). In each washing step, the precipitated proteins were centrifuged at $20,133 \times g$ for $10 \mathrm{~min}$ at $4{ }^{\circ} \mathrm{C}$. Finally, each pellet was dried at RT and dissolved in $30 \mu \mathrm{L}$ urea $(8 \mathrm{M})$. The protein concentrations were determined by measuring the 260: $280 \mathrm{~nm}$ absorbance ratios (NanoPhotometer NP80, Implen $\mathrm{GmbH}$, München, Germany).

\section{Preparing native proteins from secreted fractions}

Proteins were separated from secreted and membraneassociated fractions. Subsequently, the secreted and membrane-associated protein fractions were filtered through a $0.45 \mu \mathrm{m}$ filter to remove residual cellular material. Further, $2.5 \mathrm{~mL}$ of each fraction was subjected to a buffer exchange in $25 \mathrm{mM}$ 3-(N-morpholino) propane sulfonic acid (MOPS), with $50 \mathrm{mM} \mathrm{NaCl}$ (pH 6.2) for the secreted fraction and $25 \mathrm{mM}$ MOPS with $150 \mathrm{mM}$ $\mathrm{NaCl}$ for the membrane-associated protein fraction $(\mathrm{pH}$ of 6.2), using PD-10 desalting columns (GE Healthcare, Chicago, IL, USA). Each fraction was then eluted in a volume of $3.5 \mathrm{~mL}$. After repeating the last step three times, $14 \mathrm{~mL}$ of each eluted protein fractions was concentrated to a final volume of $1.5 \mathrm{~mL}$ using a Centriprep $10 \mathrm{k}$ filter (Merck Millipore, Darmstadt, Germany). All steps were carried out at $4{ }^{\circ} \mathrm{C}$.

\section{DNS assay}

The hydrolytic activities in the generated enzyme mixtures were determined using a DNS assay [72]. Ten microliters of the DNS reagent $(300 \mathrm{~g} / \mathrm{L}$ sodium potassium tartrate and $10 \mathrm{~g} / \mathrm{L} 3,5-\mathrm{DNS}$ in $0.4 \mathrm{M} \mathrm{NaOH}$ ) was added to $30 \mu \mathrm{L}$ of each sample and incubated for $10 \mathrm{~min}$ at $95{ }^{\circ} \mathrm{C}$ in a thermocycler. The released reducing sugars were measured spectrophotometrically at $540 \mathrm{~nm}$. Briefly, the reactions were conducted in a volume of $500 \mu \mathrm{L}$, comprising the enzyme mix and $5 \mathrm{mg} / \mathrm{mL}$ of the tested sugars. Each sample was incubated for $72 \mathrm{~h}$ at $28{ }^{\circ} \mathrm{C}$.

\section{Preparing protein samples for LC-MS/MS analysis}

Proteins were run $1 \mathrm{~cm}$ into a $10 \%$ Criterion $^{\mathrm{TM}}$ Tris- $\mathrm{HCl}$ Protein Gel (Bio-Rad Laboratories, Inc., Hercules, CA, USA) and subsequently stained with Coomassie Brilliant Blue (SERVA Electrophoresis GmbH, Heidelberg, Germany). Visualised protein bands were excised from the gel and used for peptide isolation according to a previously described method [73, 74], with modifications. The excised gel was shredded into small pieces $\left(<1 \mathrm{~mm}^{3}\right)$ and washed with acetonitrile until the Coomassie Brilliant Blue was completely removed. Subsequently, the gel pieces were dried under vacuum for 15 min (GeneVac Evaporator, GeneVac HiTechTrader, Ipswich, United 
Kingdom). Samples were reduced $(10 \mathrm{mM}$ dithiothreitol and $50 \mathrm{mM}$ ammonium bicarbonate) at $56{ }^{\circ} \mathrm{C}$ for $30 \mathrm{~min}$, washed with acetonitrile, and alkylated $(55 \mathrm{mM}$ iodoacetamide and $50 \mathrm{mM}$ ammonium bicarbonate) at RT for $20 \mathrm{~min}$. After a second washing step with acetonitrile, the samples were dried under a vacuum for $15 \mathrm{~min}$ (SpeedVac) and rehydrated in digest solution containing Trypsin Gold (V5280, Promega, Madison, WI, USA), according to the manufacturer's specifications. The enzymatic digestion was performed overnight at $37{ }^{\circ} \mathrm{C}$, with slight shaking. Peptides were extracted from the gel pieces by a series of incubation steps ( $15 \mathrm{~min}$ each) using $50 \mathrm{mM}$ ammonium bicarbonate, $100 \%$ acetonitrile, and $5 \%$ formic acid solution [75]. The collected solution was again dried under vacuum, dissolved in $1 \%$ formic acid, filtered through a $13.3 \mathrm{kDa}$ spin-filter, and subsequently subjected to LC-MS/MS analysis.

\section{LC-MS/MS analysis, protein identification, and quantification}

Protein analysis was performed using a timsTOF Pro mass spectrometer coupled with a NanoElute LC System (Bruker Daltonik GmbH, Bremen, Germany), equipped with an Aurora column $(250 \times 0.075 \mathrm{~mm}, 1.6 \mu \mathrm{m}$; IonOpticks, Hanover St., Australia). The mobile phase comprised a $0.1 \%(\mathrm{v} / \mathrm{v})$ water-formic acid mixture (A) and a $0.1 \%(\mathrm{v} / \mathrm{v})$ acetonitrile-formic acid mixture (B), which was added as a binary gradient at a flow rate of $0.4 \mu \mathrm{L} /$ min. The gradient concentration started at $2 \%(\mathrm{v} / \mathrm{v})$ B and was increased linearly to $17 \% \mathrm{~B}$ after $36 \mathrm{~min}$. After another $18 \mathrm{~min}$, the percentage of $\mathrm{C}$ was increased to $25 \%(\mathrm{v} / \mathrm{v})$ and then increased linearly to $37 \% \mathrm{~B}$ after $6 \mathrm{~min}$. After $70 \mathrm{~min}$, the concentration of B was adjusted to the final value of $95 \%(\mathrm{v} / \mathrm{v})$. The oven temperature during the measurements was $50{ }^{\circ} \mathrm{C}$.

A timsTOF pro mass spectrometer (TIMS) was used in PASEF Mode with the following settings: mass range, 100-1700 mass: charge $[\mathrm{m} / \mathrm{z}]$ ratio; ion mobility ramp, $0.6-1.6 \mathrm{~V} \cdot \mathrm{s} / \mathrm{cm}^{2} ; 10 \mathrm{MS} / \mathrm{MS}$ scans per ion mobility ramp (total cycle time $1.16 \mathrm{~s}$ ); charge range, $0-5$; active exclusion for $0.4 \mathrm{~min}$; a target intensity of 20,000 counts; and an intensity threshold of 1000 counts. Collision energy was ramped stepwise, appropriate to the ion-mobility ramp, from 20 to $59 \mathrm{eV}$. The electrospray ionisation source parameters were $1600 \mathrm{~V}$ for the capillary voltage and $3 \mathrm{~L} / \mathrm{min} \mathrm{N}_{2}$ (as dry gas) at a dry gas temperature of $180{ }^{\circ} \mathrm{C}$. The measurements were performed in a positive ion mode. Mass calibration was performed using the sodium formate cluster, and the TIMS was calibrated using Hexais (2,2-difluoroethoxy) phosphazene, Hexakis (2,2,3,3-tetrafluoropropoxy) phosphazene, and Chip cube high mass references (m/z ratios of 622,922 , and 1222 , respectively) $[76,77]$.

\section{Bioinformatics analysis}

Peptide and subsequent protein identification were performed using PEAKS software (Bioinformatics Solutions Inc., Waterloo, ON, Canada) [78-80] and the C. oleaginosus protein sequences from the UniProt database [52]. The relative protein intensities were quantified as the ratio of protein intensities normalised to the total protein intensities from the respective sample, and three biologically independent measurements were performed. For each protein, a two-sample $t$-test was performed. Glycosylated peptides from the secreted fractions were identified using the available PMTs implemented in PEAKS software. Based on the identified protein sets (protein fractions and carbohydrates), an intersection analysis was performed to generate representative groups and Venn diagrams (http://www.interactivenn.net, as of 14.09.2020) (Additional files 13, 14).

The classification of the proteins into the Gene Ontology (GO) classes biological process, cellular function, and molecular function was performed using OmicsBox software (BioBam Bioinformatics S.L., Valencia, Spain, Version 1.3.11) and the identified protein sets. First, a BLAST search against the CloudBlast database and an Interpro scan on CloudIPS was performed. Then, the proteins were mapped and annotated before they were assigned to the respective classes. For a more precise functional analysis of the identified potential hydrolases, sequences of similar enzymes were identified using Swiss-Model software [81-85] and the UniProt database [52].

Phylogenetic analyses were performed in Geneious Prime $^{\circledR}$ (v2021.1.1, Biomatters Ltd.) using the "muscle alignment" for the yeast $18 \mathrm{~s}$ sequences (American Type Culture Collection, Manassas, Virginia, USA) and the "geneious alignment" for the identified hydrolases using the "Geneious Alignment" with the consensus method majority greedy clustering.

\section{Identifying signal peptides targeting the protein-secretion pathway in C. oleaginosus}

To identify potential eukaryotic signal peptides, the SignalP5.0 [62], Phobius [86], and WoLF PSORT [87] software packages were used. The extraction software was used to screen for secreted proteins with a $-10 \cdot \lg _{\mathrm{P}}$ higher than 36 and a signal sequence targeting the pathway of protein secretion. A hit was determined only when all three programs predicted a signal peptide for the protein.

MEME Suite 5.1.1 [88] was used for motif mining and identification in the selected dataset. Specifically, the MEME tool was used for novel motif prediction of ungapped motifs in the set of proteins potentially carrying a signal peptide. The FIMO tool was used to scan for certain motifs within a specific dataset. 


\section{Abbreviations}

LC-MS/MS: Liquid chromatography-tandem mass spectrometry; MW: Molecular weight; $\mathrm{OD}_{600}$ : Optical density at $600 \mathrm{~nm}$; TIMS: TimsTOF pro mass spectrometer; YNB: Yeast nitrogen base.

\section{Supplementary Information}

The online version contains supplementary material available at https://doi. org/10.1186/s12934-021-01692-2.

Additional file 1: Fig. S1. Phylogenetic comparison of the $18 \mathrm{~S}$ ribosomal RNA genes from Cutaneontrichosporon oleaginosus, Trichosporon cutaneum, Trichosporon asahii, Rhodotorula toruloides, Yarrowia lipolytica, Lipomyces starkeyi, Komagataella pastoris and Saccharomyces cerevisiae.

Additional file 2: Fig. S2. Morphology of C. oleaginosus cultured in different carbohydrate-based media. The red scale bar represents $5 \mu \mathrm{m}$. In the left panel, microscopic images of yeast cells grown in different carbohydrate-based media are shown. C. oleaginosus cells cultured in (A) glucose, (B) cellobiose, (C) lactose, (D) maltose, (E) sucrose, and (F) trehalose are shown at 100x magnification. In the right panel, yeast cells cultured in the same carbohydrate-based media are shown following Nile red staining at $100 \times$ magnification.

Additional file 3: Fig. S3. Fatty acid content and profile of C. oleaginosus after cultivation on different disaccharides. Shown are the total fatty acid content (a) and the fatty acid profile of cultures grown for 5 days on different carbon sources and under nitrogen limitation.

Additional file 4: Fig. S4. Intersection analysis of the proteins identified in the different carbohydrate-based media. The Venn diagram shows the protein-intersection points of the investigated carbohydrates in relation to the identified proteins. The graph indicates, from top to bottom, the Venn diagrams for the secreted (a), cell wall-associated (b), and cytoplasmic fractions (c)

Additional file 5: Fig. S5. Classification of all identified proteins according to their functions in different bioprocesses.

Additional file 6: Fig. S6. Classification of all identified proteins according to their molecular functions.

Additional file 7: Fig. S7.Classification of all identified proteins according to their functions in different cellular processes.

Additional file 8: Fig. S8. Overview of the potential hydrolases identified in this study. The potential hydrolases identified in this study are listed, along with their identification (ID) numbers. The name describes the function of the enzyme with the highest sequence ID found after performing BLAST searches with the Swiss-model and UniProt databases. In addition, the reference ID is given for identification purposes. The Ref column indicates whether previous publications have identified the hydrolase of interest (+) or not (/)

Additional file 9: Fig. S9. Results of the enzyme test. Test results for each fraction for the enzymatic breakdown of the indicated carbohydrates are shown. Green highlighting indicates cleavage of the indicated disaccharide, whereas red highlighting indicates a negative reaction.

Additional file 10: Fig. S10. Overview of the most important hydrolases, as well as their function and potential substrates.

Additional file 11: Fig. S11. Phylogenetic analysis of the identified hydrolases. Major enzymes from figure EV10 are highlighted in red.

Additional file 12: Table S1. Total modified peptides.

Additional file 13: Table S2. Significants test of the detected hydrolases. Additional file 14: Table S3. Total proteins detected.

\section{Acknowledgements}

We would like to thank the Elsevier Author Services for revising the manuscript.

\section{Authors' contributions}

TF, NM, and TB conceived the experiments and analysed the data. TF wrote the manuscript. TF conducted the experiments with support from FM, ZR, MH, SP, and PS. DA, JL, and MM reviewed the manuscript. TB and NM supervised the project and reviewed the manuscript. All authors read and approved the final manuscript.

\section{Funding}

Open Access funding enabled and organized by Projekt DEAL. TB acknowledges funding by the Werner Siemens foundation for establishing the field of Synthetic Biotechnology at TUM and the Federal Ministry of Education and Research (grant number 033RC012B). The funding sources played no roles in the design of the study; in the collection, analysis, and interpretation of data; or in writing the manuscript.

\section{Availability of data and materials}

All data generated or analysed during this study are included in this published article (and its Additional files).

\section{Declarations}

Ethics approval and consent to participate

Not applicable.

\section{Consent for publication}

Not applicable.

\section{Competing interests}

The authors declare that they have no competing interests.

Received: 23 June 2021 Accepted: 5 October 2021

Published online: 28 October 2021

\section{References}

1. Masri MA, Garbe D, Mehlmer N, Brück TB. A sustainable, high-performance process for the economic production of waste-free microbial oils that can replace plant-based equivalents. Energy Environ Sci. 2019:12:2717-32

2. Liu XZ, Wang QM, Göker M, Groenewald M, Kachalkin AV, Lumbsch HT, et al. Towards an integrated phylogenetic classification of the Tremellomycetes. Stud Mycol. 2015;81:85-147

3. Bisson LF, Coons DM, Kruckeberg AL, Lewis DA. Yeast sugar transporters. Crit Rev Biochem Mol Biol. 1993;28:259-308.

4. Awad D, Bohnen F, Mehlmer N, BrueckT. Multi-factorial-guided media optimization for enhanced biomass and lipid formation by the oleaginous yeast Cutaneotrichosporon oleaginosus. Front Bioeng Biotechnol. 2019;7:54.

5. Hu C, Wu S, Wang Q, Jin G, Shen H, Zhao ZK. Simultaneous utilization of glucose and xylose for lipid production by Trichosporon cutaneum. Biotechnol Biofuels. 2011;4:25

6. Hu M, Wang J, Gao Q, Bao J. Converting lignin derived phenolic aldehydes into microbial lipid by Trichosporon cutaneum. J Biotechnol. 2018;281:81-6.

7. Liang Y, Jarosz K, Wardlow AT, Zhang J, Cui Y. Lipid production by Cryptococcus curvatus on hydrolysates derived from corn fiber and sweet sorghum bagasse following dilute acid pretreatment. Appl Biochem Biotechnol. 2014;173:2086-98.

8. Younes S, Bracharz F, Awad D, Qoura F, Mehlmer N, Brueck T. Microbial lipid production by oleaginous yeasts grown on Scenedesmus obtusiusculus microalgae biomass hydrolysate. Bioprocess Biosyst Eng. 2020;43:1629-38.

9. Masri MA, Jurkowski W, Shaigani P, Haack M, Mehlmer N, BrückT. A wastefree, microbial oil centered cyclic bio-refinery approach based on flexible macroalgae biomass. Appl Energy. 2018;224:1-12.

10. Chi Z, Zheng Y, Ma J, Chen S. Oleaginous yeast Cryptococcus curvatus culture with dark fermentation hydrogen production effluent as feedstock for microbial lipid production. Int J Hydrogen Energy. 2011;36:9542-50. 
11. Masri MA, Younes S, Haack M, Qoura F, Mehlmer N, BrückT. A seagrassbased biorefinery for generation of single-cell oils for biofuel and oleochemical production. Energy Technol. 2018;6:1026-38.

12. Kim JH, Roy A, Jouandot $D, C$ ho KH. The glucose signaling network in yeast. Biochim Biophys Acta. 2013;1830:5204-10.

13. Flores C-L, Rodríguez C, Petit T, Gancedo C. Carbohydrate and energyyielding metabolism in non-conventional yeasts. FEMS Microbiol Rev. 2000;24:507-29.

14. Lynd LR, Weimer PJ, van ZyI WH, Pretorius IS. Microbial cellulose utilization: fundamentals and biotechnology. Microbiol Mol Biol Rev. 2002;66:506-77.

15. Tchakouteu SS, Chatzifragkou A, Kalantzi O, Koutinas AA, Aggelis G, Papanikolaou S. Oleaginous yeast Cryptococcus curvatus exhibits interplay between biosynthesis of intracellular sugars and lipids. Eur J Lipid Sci Technol. 2015;117:657-72.

16. Saloheimo M, Pakula TM. The cargo and the transport system: Secreted proteins and protein secretion in Trichoderma reesei (Hypocrea jecorina). Microbiology. 2012;158:46-57.

17. Novy $V$, Nielsen F, Seiboth B, Nidetzky B. The influence of feedstock characteristics on enzyme production in Trichoderma reesei: a review on productivity, gene regulation and secretion profiles. Biotechnol Biofuels. 2019;12:238.

18. Kothari N, Bhagia S, Zaher M, Pu Y, Mittal A, Yoo CG, et al. Cellulose hydrolysis by: Clostridium thermocellum is agnostic to substrate structural properties in contrast to fungal cellulases. Green Chem. 2019;21:2810-22.

19. Mohapatra S, Mishra SS, Das SK, Thatoi H. Influence of reactors, microbial carbohydrate uptake, and metabolic pathways on ethanol production from grass biomass: a review. Int J Energy Res. 2019;43:1615-46.

20. van Maris AJA, Abbott DA, Bellissimi E, van den Brink J, Kuyper M, Luttik MAH, et al. Alcoholic fermentation of carbon sources in biomass hydrolysates by Saccharomyces cerevisiae: current status. Antonie Van Leeuwenhoek. 2006;90:391-418.

21. Jordà J, Suarez C, Carnicer M, ten Pierick A, Heijnen JJ, van Gulik W, et al. Glucose-methanol co-utilization in Pichia pastoris studied by metabolomics and instationary 13C flux analysis. BMC Syst Biol. 2013;7:17.

22. Otterstedt K, Larsson C, Bill RM, Ståhlberg A, Boles E, Hohmann S, et al. Switching the mode of metabolism in the yeast Saccharomyces cerevisiae. EMBO Rep. 2004;5:532-7.

23. Kok MV, Ozgur E. Characterization of lignocellulose biomass and model compounds by thermogravimetry. Energ Source Part A. 2017;39:134-9.

24. Brethauer S, Studer MH. Biochemical conversion processes of lignocellulosic biomass to fuels and chemicals - a review. Chimia (Aarau). 2015;69:572-81.

25. Satyawali Y, Balakrishnan M. Wastewater treatment in molasses-based alcohol distilleries for COD and color removal: a review. J Environ Manage. 2008;86:481-97.

26. Araujo-Silva R, Mafra ACO, Rojas MJ, Kopp W, Giordano RDC, Fernandez-Lafuente $\mathrm{R}$, et al. Maltose production using starch from cassava bagasse catalyzed by cross-linked $\beta$-amylase aggregates. Catal. 2018:8:170

27. Paterson AHJ. Production and uses of lactose. Adv Dairy Chem. 2009:3:105-20.

28. Yaguchi A, Robinson A, Mihealsick E, Blenner M. Metabolism of aromatics by Trichosporon oleaginosus while remaining oleaginous. Microb Cell Fact. 2017;16:1-12.

29. Mörtberg M, Neujahr HY. Transport and hydrolysis of disaccharides by Trichosporon cutaneum. J Bacteriol. 1986;168:734-8.

30. Zeng J, Zheng Y, Yu X, Yu L, Gao D, Chen S. Lignocellulosic biomass as a carbohydrate source for lipid production by Mortierella isabellina. Bioresour Technol. 2013;128:385-91.

31. Kurtzman CP, Fell JW, Boekhout T, Robert V. Methods for isolation, phenotypic characterization and maintenance of yeasts. The Yeasts. 2011;1:87-110.

32. Morrow CA, Fraser JA. Sexual reproduction and dimorphism in the pathogenic basidiomycetes. FEMS Yeast Res. 2009;9:161-77.

33. Torres-Guzmán JC, Domínguez A. HOY1, a homeo gene required for hyphal formation in Yarrowia lipolytica. Mol Cell Biol. 1997;17:6283-93.

34. Kim J, Cheon SA, Park S, Song Y, Kim J-Y. Serum-induced hypha formation in the dimorphic yeast Yarrowia lipolytica. FEMS Microbiol Lett. 2000;190:9-12.
35. Zakhartsev M, Reuss M. Cell size and morphological properties of yeast Saccharomyces cerevisiae in relation to growth temperature. FEMS Yeast Res. 2018;18:52.

36. Burgard J, Grünwald-Gruber C, Altmann F, Zanghellini J, Valli M, Mattanovich D, et al. The secretome of Pichia pastoris in fed-batch cultivations is largely independent of the carbon source but changes quantitatively over cultivation time. Microb Biotechnol. 2020;13:479-94.

37. Bauer S, Vasu P, Persson S, Mort AJ, Somerville CR. Development and application of a suite of polysaccharide-degrading enzymes for analyzing plant cell walls. Proc Natl Acad Sci U S A. 2006;103:11417-22.

38. Cheng YS, Huang CH, Chen CC, Huang TY, Ko TP, Huang JW, et al. Structural and mutagenetic analyses of a 1,3-1,4- $\beta$-glucanase from Paecilomyces thermophila. Biochim Biophys Acta. 2014;1844:366-73.

39. Han P, Zhou P, Hu S, Yang S, Yan Q, Jiang Z. A novel multifunctional a-amylase from the thermophilic fungus Malbranchea cinnamomea: Biochemical characterization and three-dimensional structure. Appl Biochem Biotechnol. 2013;170:420-35.

40. Cutfield JF, Sullivan PA, Cutfield SM. Minor structural consequences of alternative CUG codon usage (Ser for Leu) in Candida albicans exoglucanase. Protein Eng Des Sel. 2000;13:735-8.

41. Nakkharat $P$, Haltrich D. Purification and characterisation of an intracellular enzyme with $\beta$-glucosidase and $\beta$-galactosidase activity from the thermophilic fungus Talaromyces thermophilus CBS 236.58. J Biotechnol. 2006;123:304-13.

42. Hedin LE, Illergård K, Elofsson A. An introduction to membrane proteins. J Proteome Res. 2011;10:3324-31.

43. Tsukada T, Igarashi K, Yoshida M, Samejima M. Molecular cloning and characterization of two intracellular $\beta$-glucosidases belonging to glycoside hydrolase family 1 from the basidiomycete Phanerochaete chrysosporium. Appl Microbiol Biotechnol. 2006;73:807-14.

44. Dotsenko GS, Semenova MV, Sinitsyna OA, Hinz SWA, Wery J, Zorov IN, et al. Cloning, purification, and characterization of galactomannandegrading enzymes from Myceliophthora thermophila. Biochemistry. 2012;77:1303-11.

45. Lyhne-Iversen L, Hobley TJ, Kaasgaard SG, Harris P. Structure of Bacillus halmapalus a-amylase crystallized with and without the substrate analogue acarbose and maltose. Acta Crystallogr Sect F Struct Biol Cryst Commun. 2006;62:849-54.

46. Rutkiewicz M, Bujacz A, Bujacz G. Structural features of cold-adapted dimeric GH2 $\beta$-D-galactosidase from Arthrobacter sp. 32cB. Biochim Biophys Acta. 2019;1867:776-86.

47. Shen X, Saburi W, Gai Z, Kato K, Ojima-Kato T, Yu J, et al. Structural analysis of the a-glucosidase HaG provides new insights into substrate specificity and catalytic mechanism. Acta Crystallogr Sect D Biol Crystallogr. 2015;71:1382-91.

48. Williamson PR, Huber MA, Bennett JE. Role of maltase in the utilization of sucrose by Candida albicans. Biochem J. 1993;291:765-71.

49. Satoh T, Toshimori T, Yan G, Yamaguchi T, Kato K. Structural basis for two-step glucose trimming by glucosidase II involved in ER glycoprotein quality control. Sci Rep. 2016;6:1-7.

50. Alblova M, Smidova A, Docekal V, Vesely J, Herman P, Obsilova V, et al. Molecular basis of the 14-3-3 protein-dependent activation of yeast neutral trehalase Nth1. Proc Natl Acad Sci U S A. 2017;114:E9811-20.

51. Watanabe K, Hata Y, Kizaki H, Katsube Y, Suzuki Y. The refined crystal structure of Bacillus cereus oligo-1,6-glucosidase at $2.0 \AA$ resolution: structural characterization of proline-substitution sites for protein thermostabilization. J Mol Biol. 1997;269:142-53.

52. Bateman A. UniProt: a worldwide hub of protein knowledge. Nucleic Acids Res. 2019;47:D506-15.

53. Galazka JM, Tian C, Beeson WT, Martinez B, Glass NL, Cate JHD. Cellodextrin transport in yeast for improved biofuel production. Science. 2010;330:84-6.

54. Carvalho-Silva M, Spencer-Martins I. Modes of lactose uptake in the yeast species Kluyveromyces marxianus. Antonie Van Leeuwenhoek. 1990;57:77-81.

55. Wanderley KJ, Torres FA, Moraes LM, Ulhoa CJ. Biochemical characterization of a-amylase from the yeast Cryptococcus flavus. FEMS Microbiol Lett. 2004;231:165-9.

56. Vidgren V, Ruohonen L, Londesborough J. Characterization and functional analysis of the MAL and MPH loci for maltose utilization in some ale and lager yeast strains. Appl Environ Microbiol. 2005;71:7846-57. 
57. Viana PA, de Rezende ST, Lopes FMP, Machado SG, Maitan GP, da Silva Coelho VT, et al. a-Galactosidases production by Debaryomyces hanseni UFV-1. Food Sci Biotechnol. 2011;20:601-6.

58. Basso TO, de Kok S, Dario M, do Espirito-Santo JCA, Müller G, Schlölg PS, et al. Engineering topology and kinetics of sucrose metabolism in Saccharomyces cerevisiae for improved ethanol yield. Metab Eng. 2011;13:694-703.

59. Basso LC, De Amorim HV, De Oliveira AJ, Lopes ML. Yeast selection for fuel ethanol production in Brazil. FEMS Yeast Res. 2008:8:1155-63.

60. Costa EA, Subramanian K, Nunnari J, Weissman JS. Defining the physiological role of SRP in protein-targeting efficiency and specificity. Science. 2018:359:689-92.

61. Owji H, Nezafat N, Negahdaripour M, Hajiebrahimi A, Ghasemi Y. A comprehensive review of signal peptides: structure, roles, and applications. Eur J Cell Biol. 2018;97:422-41.

62. Nielsen $\mathrm{H}$, Tsirigos KD, Brunak S, von Heijne $\mathrm{G}$. A brief history of protein sorting prediction. Protein J. 2019;38:200-16.

63. Waters MG, Evans EA, Blobel G. Prepro-alpha-factor has a cleavable signal sequence. J Biol Chem. 1988;263:6209-14.

64. Macauley-Patrick S, Fazenda ML, McNeil B, Harvey LM. Heterologous protein production using the Pichia pastoris expression system. Yeast. 2005:22:249-70.

65. Enderlin CS, Ogrydziak DM. Cloning, nucleotide sequence and functions of XPR6, which codes for a dibasic processing endoprotease from the yeast Yarrowia lipolytica. Yeast. 1994;10:67-79.

66. Nicaud JM, Fabre E, Beckerich JM, Fournier P, Gaillardin C. Cloning, sequencing and amplification of the alkaline extracellular protease (XPR2) gene of the yeast Yarrowia lipolytica. J Biotechnol. 1989;12:285-97.

67. Nicaud JM, Madzak C, Van Den Broek P, Gysler C, Duboc P, Niederberger $P$, et al. Protein expression and secretion in the yeast Yarrowia lipolytica. FEMS Yeast Res. 2002;2:371-9.

68. Park Y-K, Vandermies M, Soudier P, Telek S, Thomas S, Nicaud J-M, et al. Efficient expression vectors and host strain for the production of recombinant proteins by Yarrowia lipolytica in process conditions. Microb Cell Factories. 2019:18:1-12.

69. Griffiths MJ, van Hille RP, Harrison STL. Selection of direct transesterification as the preferred method for assay of fatty acid content of microalgae Lipids. 2010;45:1053-60.

70. Woortman DV, Fuchs T, Striegel L, Fuchs M, Weber N, BrückTB, et al. Microalgae a superior source of folates: quantification of folates in halophile microalgae by stable isotope dilution assay. Front Bioeng Biotechnol. 2020:7:481.

71. Greenspan P, Mayer EP, Fowler SD. Nile red: a selective fluorescent stain for intracellular lipid droplets. J Cell Biol. 1985;100:965-73.

72. Wood IP, Elliston A, Ryden P, Bancroft I, Roberts IN, Waldron KW. Rapid quantification of reducing sugars in biomass hydrolysates: Improving the speed and precision of the dinitrosalicylic acid assay. Biomass Bioenergy. 2012;44:117-21.
73. Shevchenko A, Wilm M, Vorm O, Mann M. Mass spectrometric sequencing of proteins from silver-stained polyacrylamide gels. Anal Chem. 1996:68:850-8

74. Granvogl B, Gruber P, Eichacker LA. Standardisation of rapid in-gel digestion by mass spectrometry. Proteomics. 2007;7:642-54.

75. Awad D, Brueck T. Optimization of protein isolation by proteomic qualification from Cutaneotrichosporon oleaginosus. Anal Bioanal Chem Springer. 2020;412:449-62. https://doi.org/10.1007/s00216-019-02254-7.

76. Sandow JJ, Infusini G, Dagley LF, Larsen R, Webb Al. Simplified highthroughput methods for deep proteome analysis on the timsTOF Pro. bioRxiv. 2019. https://doi.org/10.1101/657908.

77. Meier F, Brunner AD, Koch S, Koch H, Lubeck M, Krause M, et al. Online parallel accumulation-serial fragmentation (PASEF) with a novel trapped ion mobility mass spectrometer. Mol Cell Proteomics. 2018;17:2534-45.

78. Tran NH, Qiao R, Xin L, Chen X, Liu C, Zhang X, et al. Deep learning enables de novo peptide sequencing from data-independent-acquisition mass spectrometry. Nat Methods. 2019;16:63-6.

79. Tran NH, Zhang X, Xin L, Shan B, Li M. De novo peptide sequencing by deep learning. Proc Natl Acad Sci U S A. 2017;114:8247-52.

80. Tran NH, Rahman MZ, He L, Xin L, Shan B, Li M. Complete de novo assembly of monoclonal antibody sequences. Sci Rep. 2016;6:31730.

81. Benkert P, Biasini M, Schwede T. Toward the estimation of the absolute quality of individual protein structure models. Bioinformatics. 2011;27:343-50.

82. Bertoni M, Kiefer F, Biasini M, Bordoli L, Schwede T. Modeling protein quaternary structure of homo- and hetero-oligomers beyond binary interactions by homology. Sci Rep. 2017;7:1-15.

83. Guex N, Peitsch MC, Schwede T. Automated comparative protein structure modeling with SWISS-MODEL and Swiss-PdbViewer: a historical perspective. Electrophoresis. 2009;30:S162-73.

84. Studer G, Rempfer C, Waterhouse AM, Gumienny R, Haas J, Schwede T. QMEANDisCo-distance constraints applied on model quality estimation. Bioinformatics. 2020;36:1765-71.

85. Waterhouse A, Bertoni M, Bienert S, Studer G, Tauriello G, Gumienny $R$, et al. SWISS-MODEL: homology modelling of protein structures and complexes. Nucleic Acids Res. 2018;46:W296-303.

86. Käll L, Krogh A, Sonnhammer ELL. A combined transmembrane topology and signal peptide prediction method. J Mol Biol. 2004;338:1027-36.

87. Nakai K, Kanehisa M. A knowledge base for predicting protein localization sites in eukaryotic cells. Genomics. 1992;14:897-911.

88. Bailey TL, Bodén M, Buske FA, Frith M, Grant CE, Clementi L, et al. MEME SUITE: tools for motif discovery and searching. Nucleic Acids Res. 2009;37:W202-8.

\section{Publisher's Note}

Springer Nature remains neutral with regard to jurisdictional claims in published maps and institutional affiliations.
Ready to submit your research? Choose BMC and benefit from:

- fast, convenient online submission

- thorough peer review by experienced researchers in your field

- rapid publication on acceptance

- support for research data, including large and complex data types

- gold Open Access which fosters wider collaboration and increased citations

- maximum visibility for your research: over 100M website views per year

At $\mathrm{BMC}$, research is always in progress.

Learn more biomedcentral.com/submissions 